\title{
Experimental and petrological studies of melt inclusions in phenocrysts from mantle-derived magmas: an overview of techniques, advantages and complications
}

\author{
Leonid V. Danyushevsky $^{\mathrm{a}, *}$, Andrew W. McNeill ${ }^{\mathrm{a}, 1}$, Alexander V. Sobolev ${ }^{\mathrm{b}, \mathrm{c}}$ \\ ${ }^{a}$ School of Earth Sciences and Centre for Ore Deposit Research, University of Tasmania, GPO Box 272-79, \\ Hobart TAS 7001, Australia \\ ${ }^{\mathrm{b}}$ Vernadsky Institute of Geochemistry, Russian Academy of Science, Kosigin 19, Moscow 117975, Russia \\ ${ }^{\mathrm{c}}$ Max-Planck-Institut für Chemie, Postfach 3060, 55020 Mainz, Germany
}

\begin{abstract}
Melt inclusions in phenocrysts are a potentially powerful tool in petrological research that can provide the only direct information available on the physical parameters $(P, T$ and melt composition) of crystallisation at various stages in the evolution of magmatic systems. However, melt inclusions also differ in principle from other parts of the magmatic system in that their composition, after trapping, may be controlled by the composition of the host phenocryst and therefore the direct application of our understanding of macro-scale magmatic processes to the interpretation of melt inclusion data can lead to erroneous conclusions. Our results indicate that the compositions of melt inclusions in early formed phenocrysts (olivine, pyroxene, plagioclase and spinel), often of most interest in petrological studies, can be affected by processes such as volatile dissociation, oxidation and/or partial re-equilibration with their host, both during natural cooling and homogenisation experiments. In particular, melt inclusions in all minerals are prone to hydrogen diffusion into or out of the inclusions after trapping and prior to eruption, and during homogenisation experiments. If not taken into account, this can significantly affect the crystallisation temperatures derived from the homogenisation experiments. Melt inclusions in highmagnesian olivine phenocrysts commonly have lower Fe contents compared to the initially trapped composition due to reequilibration with the host at lower temperatures. This often leads to the appearance of sulphide globules and in some cases high-magnesian clinopyroxene daughter crystals, and may cause an increase in the oxidation state of the inclusions. Homogenised melt inclusions in plagioclase phenocrysts in MORB usually have lower $\mathrm{Ti}$ and $\mathrm{Fe}$, and higher $\mathrm{Si}$ contents compared to the melt composition at the moment of trapping. However, homogenisation experiments can provide reliable estimates of trapping temperature and the $\mathrm{MgO}, \mathrm{Al}_{2} \mathrm{O}_{3}, \mathrm{CaO}, \mathrm{Na}_{2} \mathrm{O}$, and $\mathrm{K}_{2} \mathrm{O}$ contents of the host magma at the moment of trapping. Some of these processes can be identified by observing the behaviour of melt inclusions during homogenisation experiments using low-inertia visually controlled heating stages, and their effects can be minimised by using appropriate experimental conditions as determined by kinetic experiments, ideally completed for each phenocryst type in every sample. We also discuss general aspects of melt inclusion studies aimed at recovering $\mathrm{H}_{2} \mathrm{O}$ content of primary mantle-derived magmas and demonstrate that, in cases of low-pressure crystallisation, it is important to identify the
\end{abstract}

\footnotetext{
* Corresponding author. Tel.: +61-3-6226-2469; fax: +61-3-6223-2547.

E-mail addresses: L.Dan@utas.edu.au (L.V. Danyushevsky), mcneilla@pasminco.com.au (A.W. McNeill).

${ }^{1}$ Now at Pasminco Exploration, 2 Arthur Street, Rosebery, Tasmania 7470, Australia.
} 
first liquidus (most magnesian) olivine that crystallised from these magmas. (C) 2002 Elsevier Science B.V. All rights reserved.

Keywords: Melt inclusion; Homogenisation experiments; $\mathrm{H}_{2} \mathrm{O}$; Primary magmas; Phenocrysts; Plagioclase

\section{Introduction}

The existence of melt inclusions, small portions of melt trapped by growing crystals during magma evolution prior to and during eruptions, has been recognised for many years (Anderson, 1974; Clocchiatti, 1975; Sobolev and Kostyuk, 1975; Sobolev, 1983; Roedder, 1984 and references therein). As summarised by Roedder (1979), melt inclusion studies can provide valuable information on crystallisation temperatures, the sequence of phase changes in the host magma during cooling, constraints on cooling rates, the composition and volatile content of the host magma and liquid line of descent.

However, the importance of melt inclusions for petrological and geochemical studies of magma genesis has only been fully realised in the past two decades following the development of microbeam analytical techniques. A large number of recent studies have described the compositions of melt inclusions in various phenocrysts from different magma types (e.g., Sobolev and Shimizu, 1993; Nielsen et al., 1995; Gurenko et al., 1996; Sobolev and Chaussidon, 1996; Sobolev, 1996; Kamenetsky et al., 1997; Metrich et al., 1999; Sobolev et al., 2000; and references therein). However, since the pioneering works summarised by Roedder (1984), the methodological aspects of melt inclusion research have received considerably less attention (see Sobolev, 1983; Sobolev et al., 1983, 1990; Qin et al., 1992; Tait, 1992; Sobolev and Danyushevsky, 1994; Lu et al., 1995; Nakamura and Shimakita, 1998; Danyushevsky et al., 2000a; Gaetani and Watson, 2000).

In this contribution, we discuss the techniques used in experimental studies of melt inclusions and some processes that may affect the compositions of melt inclusions after trapping. We do not attempt to cover all problems associated with melt inclusion studies. Correspondence of the trapped composition to the host magma, coexistence of compositionally contrasting melt inclusions in a single grain and origin of 'exotic' melt inclusions are outside the scope of this paper (see
Lu et al., 1995; Sobolev et al., 1990; Sobolev, 1996, 2001).

\section{Experimental studies of melt inclusions}

The purpose of experimental studies of melt inclusions is to reheat the inclusions to the temperature at which they were trapped, thus reversing the phase changes that occurred during natural cooling, i.e., crystallisation and formation of the shrinkage/fluid bubble, and then quench the restored trapped composition for further analysis. A detailed description of the theory of the homogenisation of melt inclusions is given in Roedder (1979, 1984 and references therein). The following discussion assumes that the composition of the host phenocryst does not change after the inclusion is trapped, and that the melt was fluidsaturated at the moment of trapping.

Important differences may exist between the physical conditions of the phenocryst, and any melt inclusions it hosts, during crystallisation and experimental reheating. For example, the pressure on the phenocryst during $1 \mathrm{~atm}$ experiments is always different (lower) than during natural cooling. The pressure inside melt inclusions at high temperatures will tend to increase toward the pressure at the time of trapping. If the phenocryst is capable of containing the high pressure, a pressure gradient (which is absent at the moment of trapping) will result. If the phenocryst cannot preserve the pressure inside the melt inclusions during an experiment, the pressure inside inclusions will be lower than the pressure of trapping (see Tait, 1992 for further discussion). In both cases, differences between experimental and natural conditions will result.

Another important difference between experimental and natural conditions is that during homogenisation experiments the phenocryst may control the composition of melt inclusions due to its dominant size (i.e., when chemical equilibrium is established during an experiment, the composition of a melt inclusion is a function of the physical conditions of 
the experiment and the phenocryst composition), whereas during crystallisation in macro systems, the melt composition controls the composition of crystallising phases (i.e., the composition of a phenocryst is a function of the physical conditions and melt composition). As the physical parameters of homogenisation experiment may differ from the trapping conditions (see above), it is undesirable to equilibrate a melt inclusion with its host, as this may result in a change in the inclusion's composition.

An ideal homogenisation experiment is shown on Fig. 1. A typical melt inclusion at room temperature comprises a rim of the host mineral, a shrinkage/fluid bubble, and the recrystallised residual melt (Roedder, 1979; Fig. 1a). The host mineral always crystallises as an overgrowth on the walls of the melt inclusion because the pre-existing phase boundary (inclusion wall) has a low nucleation energy (e.g., Roedder, 1979). As the rim of the host mineral is usually optically indistinguishable from the host phenocryst, the observed size of the inclusion is smaller that its real size. The phase composition of a melt inclusion will depend on the temperature gap between trapping and eruption and the efficiency of quenching during eruption (Roedder, 1979).

With increasing temperature, during a homogenisation experiment, crystalline phases inside the inclusion melt and the bubble decreases in size (Fig. 1b). At a certain point, all microlites inside the inclusion will melt but the bubble is still present and there is some overgrowth remaining on the host phenocryst (Fig. 1c). Eventually, all crystalline phases inside the inclusion will have melted and the bubble disappears (Fig. 1d). At this moment, the experiment should be quenched.

From this simple analysis, it is clear that the kinetics of melting during a homogenisation experiment are important. If the temperature is increased too rapidly (i.e., the rate of heating is faster than the rate of melting within the inclusion), then the melting process will lag behind, and at any given moment, the conditions inside the inclusion will correspond to a lower temperature than the experimental temperature. Thus, rapid heating results in overheating (i.e., homogenisation is observed at a higher temperature than it occurs; note, however, that if the experiment is quenched immediately after homogenisation, the composition of an overheated inclusion should correspond

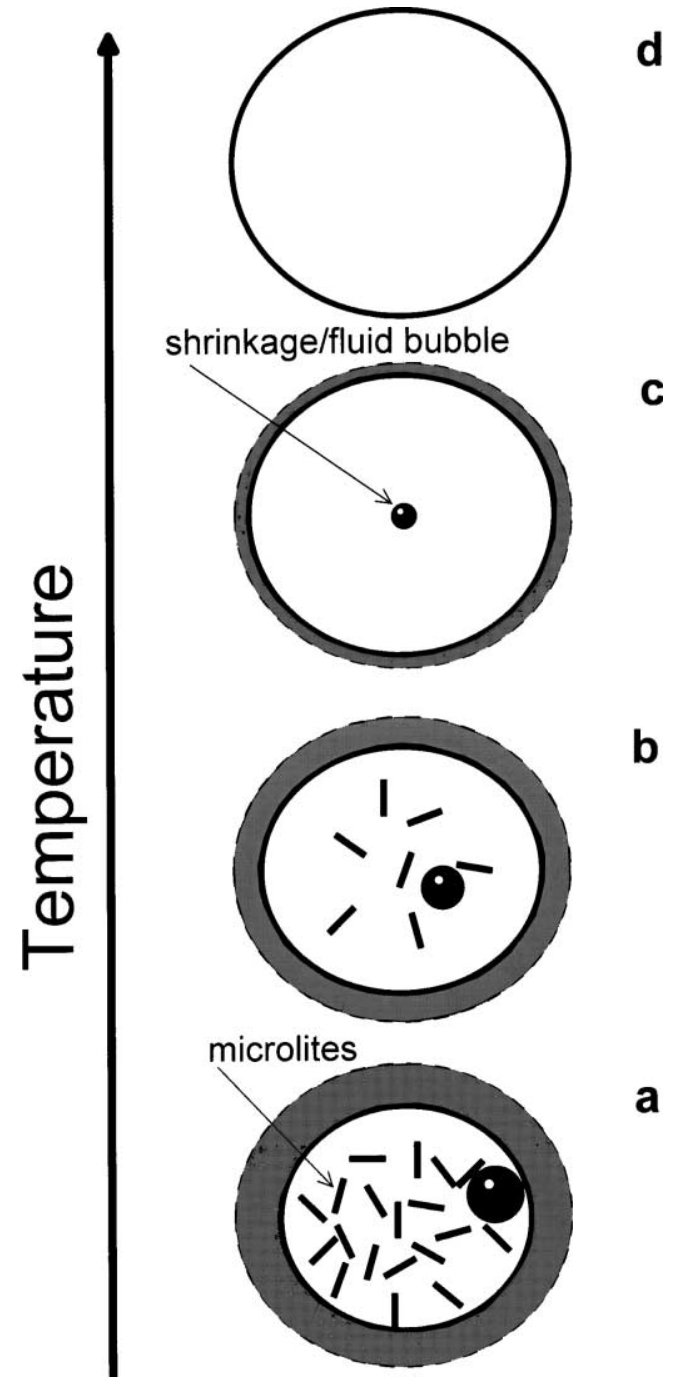

Fig. 1. Illustration showing an ideal melt inclusion homogenisation experiment. The solid bold line represents the visible boundary of the melt inclusion. Dashed bold line shows the actual size of the melt inclusion. Shaded grey area on the walls of the inclusion represent the host mineral that crystallised from the inclusion volume after trapping forming an overgrowth on the walls of the inclusion. See text for discussion.

to the trapped composition). Slow heating, on the other hand, will lead to re-equilibration (i.e., equilibration at conditions different to those at the moment of trapping) of a melt inclusion with its host.

Experimental studies of melt inclusions will produce reliable results when no mass transfer has occurred through the inclusion-host interface. In such 
cases, using an appropriate heating rate that precludes re-equilibration with the host during the experiment, the composition of an inclusion at the moment of homogenisation (Fig. 1d) corresponds to the trapped composition. However, if some mass transfer has occurred (i.e., re-equilibration of the inclusion with its host after trapping, but before natural quenching), then the composition of the homogenised melt inclusion will differ from the trapped composition and will not be in equilibrium with the host. If the compositions of the host mineral and the homogenised melt inclusion are known, such disequilibrium can be deduced using mineral-melt equilibrium models (e.g., Ariskin et al., 1993). Currently, these models are most reliable for major elements, but our understanding of trace element partitioning as a function of pressure, temperature and other physical parameters is constantly improving (e.g., Blundy et al., 1996; Libourel, 1999; Sugawara, 2000).

The foregoing discussion highlights the danger of re-equilibrating a melt inclusion with its host during an experiment. When re-equilibration occurs, the composition of the melt inclusion is forced into equilibrium with the host at the experimental conditions, depriving us of any means to reveal changes in the inclusion composition after trapping and before natural quenching. It is important to note that reequilibration with the host during an experiment will not necessarily return the composition of the melt inclusion to its initially trapped composition, as the physical parameters of an experiment may differ from the trapping conditions, as discussed above. We are not suggesting that re-equilibration equally affects all elements in an inclusion or that every experiment results in noticeable re-equilibration of inclusions with their host. For example, elements that are incompatible with the host are prone to re-equilibration significantly less than compatible elements, and their concentrations are unlikely to suffer any changes during reheating experiments. We would like to emphasise the main underlined principle of experimental studies: melt inclusions should be kept at high temperatures for a minimum possible time during an experiment.

The appropriate heating rate for homogenisation experiments can be established from kinetic experiments (e.g., Sobolev and Kostyuk, 1975; Sobolev et al., 1988; Sobolev and Danyushevsky, 1994). Kinetic experiments involve the continuous reheating a melt inclusion at different rates and then observing the homogenisation temperature obtained at each rate. Fig. 2a shows an example of kinetic experiments for plagioclase phenocrysts from MORB. The melt inclusion is first heated at the highest rate $\left(50{ }^{\circ} \mathrm{C} / \mathrm{min}\right)$. After homogenisation, the inclusion is cooled and recrystallised and then homogenised again at a slower
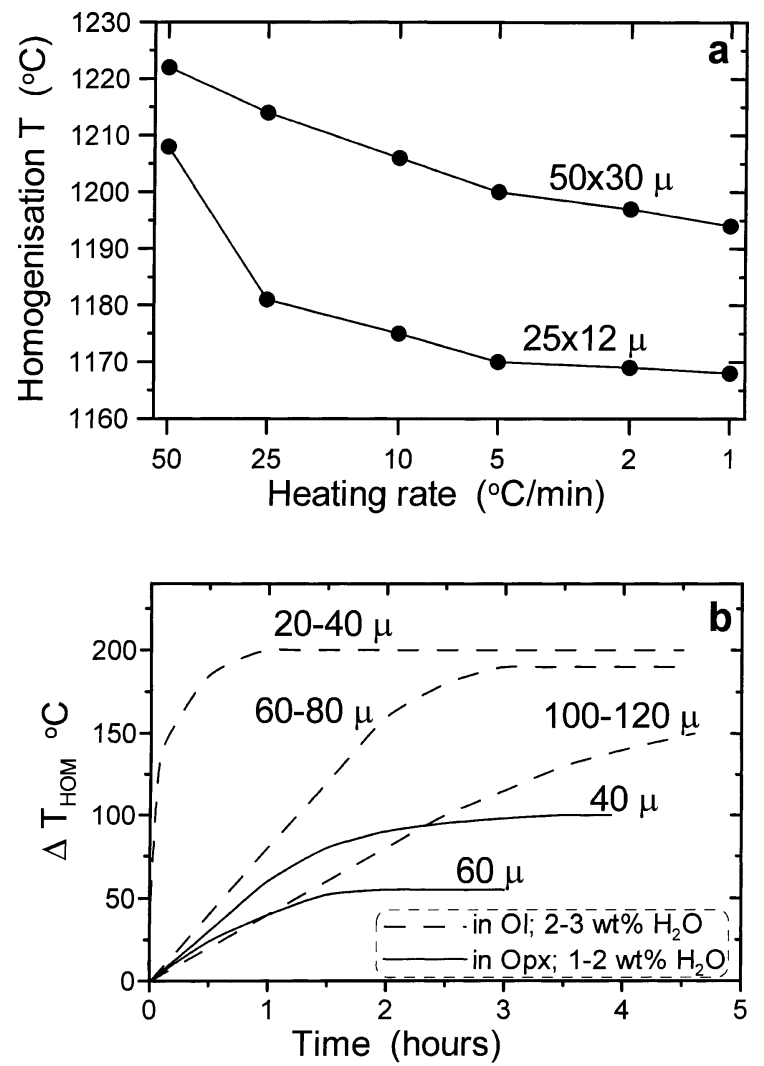

Fig. 2. (a) Kinetic experiments using a plagioclase phenocryst from MORB (ODP Hole 504B). Homogenisation temperatures were recorded for two inclusions of different size as indicated on the figure. The larger inclusion requires significantly slower heating rates than have been used in the experiment since all inclusions in one grain are expected to be trapped at a similar temperature. Heating rates are effective from temperatures 50 to $70{ }^{\circ} \mathrm{C}$ lower than the true homogenisation temperature. (b) Kinetic experiments using melt inclusions of different sizes in olivine and orthopyroxene phenocrysts from Tongan boninites (Sobolev and Danyushevsky, 1994). Experiments indicate an increase of the homogenisation temperature caused by dissociation of $\mathrm{H}_{2} \mathrm{O}$ within inclusions when they are kept at high temperatures $\left(>1150{ }^{\circ} \mathrm{C}\right)$. Note there is a smaller effect from $\mathrm{H}_{2} \mathrm{O}$ dissociation in larger inclusions. See text for discussion. 
Table 1

Approximate heating rates for melt inclusions from several magma types

\begin{tabular}{|c|c|c|c|c|c|}
\hline Phenocryst & $\begin{array}{l}\text { Inclusion } \\
\text { size }(\mu \mathrm{m})\end{array}$ & Magma type & $\begin{array}{l}\text { Homogenisation } \\
\text { temperature }\left({ }^{\circ} \mathrm{C}\right)\end{array}$ & $\begin{array}{l}\text { Heating rate } \\
\left({ }^{\circ} \mathrm{C} / \mathrm{min}\right)\end{array}$ & Comments \\
\hline Olivine & $\sim 30$ & $\begin{array}{l}\text { "anhydrous" } \\
\text { tholeiitic }\end{array}$ & $1190-1250$ & $1-2$ & $\begin{array}{l}\text { heating rate is effective from temperatures } \sim 50 \text { to } \\
70{ }^{\circ} \mathrm{C} \text { below expected homogenisation temperature }\end{array}$ \\
\hline Plagioclase & $\sim 30$ & $\begin{array}{l}\text { "anhydrous" } \\
\text { tholeiitic }\end{array}$ & $1190-1250$ & 2 & $\begin{array}{l}\text { heating rate is effective from temperatures } \sim 50 \text { to } \\
70{ }^{\circ} \mathrm{C} \text { below expected homogenisation temperature }\end{array}$ \\
\hline Clinopyroxene & $\sim 30$ & $\begin{array}{l}\text { "anhydrous" } \\
\text { tholeiitic }\end{array}$ & $1190-1250$ & $0.5-1$ & $\begin{array}{l}\text { heating rate is effective from temperatures } \sim 50 \text { to } \\
70{ }^{\circ} \mathrm{C} \text { below expected homogenisation temperature }\end{array}$ \\
\hline Olivine & $100-150$ & $\begin{array}{l}\text { tholeiitic, } \\
\text { boninitic, } 1.5 \\
-3 \text { wt. } \% \mathrm{H}_{2} \mathrm{O}\end{array}$ & $1250-1350$ & $100-200$ & heating rate is effective above $1060-1100{ }^{\circ} \mathrm{C}^{\mathrm{b}}$ \\
\hline $\begin{array}{l}\text { Orthopyroxene, } \\
\text { clinopyroxene }\end{array}$ & $50-80$ & $\begin{array}{l}\text { tholeiitic, } \\
\text { boninitic, } 1.5 \\
-3 \text { wt. } \% \mathrm{H}_{2} \mathrm{O}\end{array}$ & $1150-1250$ & $50-100$ & heating rate is effective above $1060-1100{ }^{\circ} \mathrm{C}^{\mathrm{b}}$ \\
\hline Plagioclase & $50-80$ & $\begin{array}{l}\text { tholeiitic, } \\
\text { boninitic, } 1.5 \\
-3 \text { wt. } \% \mathrm{H}_{2} \mathrm{O}\end{array}$ & $1050-1100$ & 100 & heating rate is effective above $950{ }^{\circ} \mathrm{C}^{\mathrm{c}}$ \\
\hline
\end{tabular}

\footnotetext{
a Sobolev et al., 1988.

b Sobolev and Danyushevsky, 1994.

c Danyushevsky et al., 1997.
}

rate. This process is repeated until the homogenisation temperature becomes asymptotic, and the rate at which this happens is deemed the appropriate heating rate (between 2 and $5{ }^{\circ} \mathrm{C} / \mathrm{min}$ for the smaller inclusion on Fig. 2a). Heating inclusions at a slower rate will not result in a lower homogenisation temperature, but will lead to re-equilibration of the inclusions with their host (as discussed above). The optimal heating rate is strongly dependent on the size of inclusions (Fig. 2a). Ideally, kinetic experiments should be conducted for every phenocryst type (i.e., olivine, plagioclase, etc.) in every sample studied.

Table 1 presents experimentally determined heating rates for "anhydrous" tholeiitic melt inclusions, $\sim 30 \mu \mathrm{m}$ in diameter, with homogenisation temperatures in the range $1190-1250{ }^{\circ} \mathrm{C}$. These rates are effective from $\sim 50$ to $70{ }^{\circ} \mathrm{C}$ lower than the expected homogenisation temperature. Thus, the melt inclusions are kept at temperatures close to homogenisation for durations of $\sim 30 \mathrm{~min}$ to $1 \mathrm{~h}$. Melt inclusions in clinopyroxene require the slowest heating rate (longest time at high temperature), whereas inclusions in plagioclase generally allow the fastest heating rate. The heating rate at lower temperatures $\left(<1150{ }^{\circ} \mathrm{C}\right)$ does not influence the homogenisation temperature.

Although kinetic experiments provide important information on optimal heating rates, the rate of melting of individual melt inclusions can vary and some inclusions may be overheated even when the heating rate was constrained by kinetic experiments. Overheated melt inclusions can be identified by comparing the homogenisation temperatures of inclusions in phenocrysts of a similar composition (Fig. 3). A

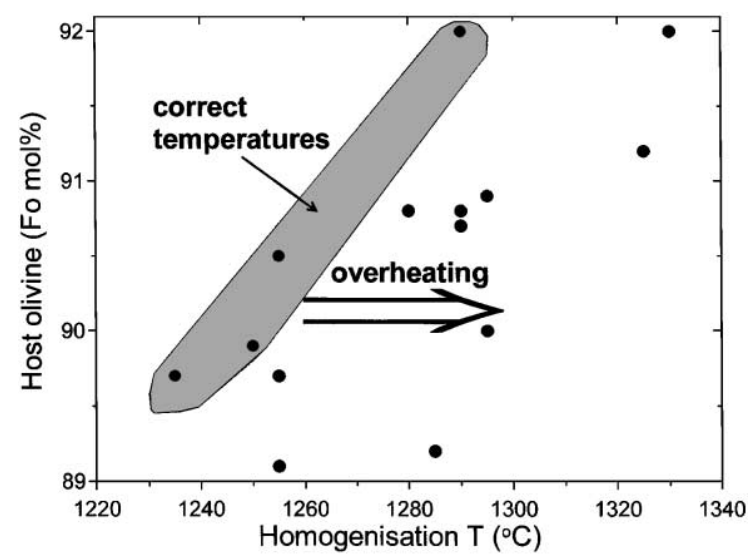

Fig. 3. Homogenisation temperatures of melt inclusions in olivine phenocrysts from Tongan boninites. The range of homogenisation temperatures at a given host composition is caused by overheating. See Sobolev and Danyushevsky (1994) for a detailed description of experimental procedures. See text for discussion. 
necessary requirement for such a comparison is that inclusions have similar compositions, i.e., they represent a single liquid line of descent.

An example of the readjustments of the melt inclusion-host phenocryst pair to experimental conditions is shown on Fig. 4. When melt inclusions in plagioclase from MORB are kept at temperatures close to their trapping temperatures (between stages $\mathrm{b}$ and c, Fig. 1) longer than it is necessary, olivine microlites inside inclusions may recrystallise to form a single crystal. Once such a crystal is formed, it would not melt at temperatures at least $20{ }^{\circ} \mathrm{C}$ higher than the true homogenisation temperature, and in some cases, the shrinkage/fluid bubble disappeared before the olivine crystal melted. Our preferred explanation is that this results from a decrease of pressure inside such inclusions due to the inability of the host crystal to contain the pressure gradient during experiments, as discussed above. Since MORB melts are olivine+ plagioclase cotectic (e.g., Grove et al., 1992), the olivine microlites inside inclusions should melt simultaneously with complete melting of the plagioclase rim on the walls and homogenisation of the inclusion, as is often observed in experiments (McNeill, 1997). If the effect of pressure on the olivine liquidus temperature is slightly less than it is on the plagioclase liquidus temperature, than the decrease of pressure inside an inclusion during an experiment will enhance olivine stability and produce the observed effect.

The preceding discussion highlights the importance of visual control during homogenisation experiments, which is possible when using a microscopemounted heating stage (see Sobolev et al., 1980 for a description of a low-thermal inertia heating stage). However, when experiments are conducted in a $1 \mathrm{~atm}$ vertical furnace without visual control, it is impossible

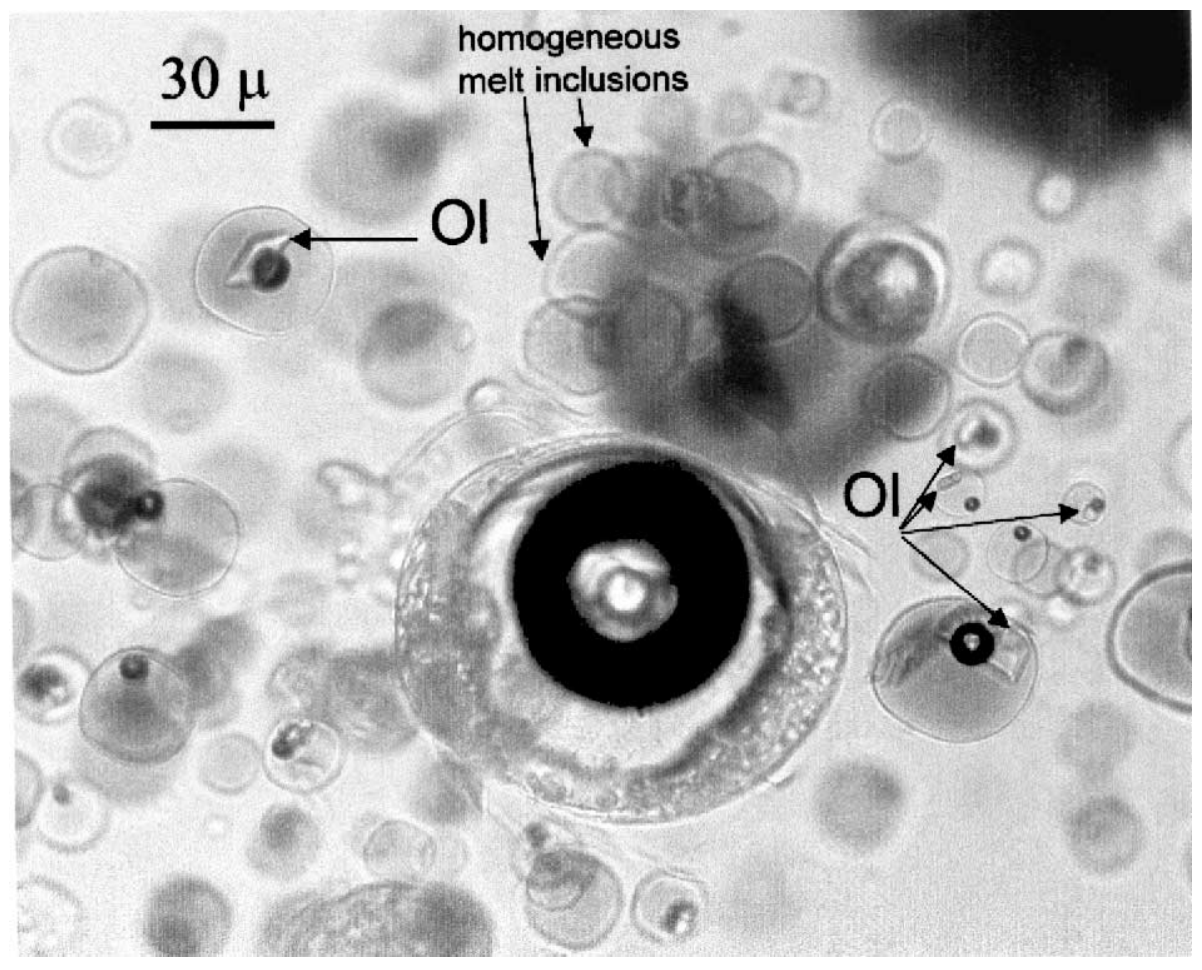

Fig. 4. Melt inclusions in plagioclase phenocryst P118 from MORB sample D9-1 (Gorda ridge) quenched from $1200{ }^{\circ} \mathrm{C}$. Since most inclusions have homogenised at this temperature, it is considered the true trapping temperature of these inclusions. Several of the inclusions contain a large olivine crystal that would not melt at the inferred trapping temperature. These olivine crystals formed during the experiment as a result of recrystallisation of small olivine microlites initially present in all inclusions. The large air bubble in the centre formed in place of a melt inclusion that leaked during the experiment. See text for discussion. 
to observe phase transformations within inclusions or to determine the appropriate duration/heating rate for the experiments.

If phase transformations cannot be observed, the presence of large olivine crystals inside some melt inclusions, as discussed above (this issue is taken as an example), may be interpreted as an indication that the inclusions were trapped at a higher temperature. Indeed, such olivine crystals have been observed in a number of studies of melt inclusions in MORB plagioclase which have used $1 \mathrm{~atm}$ vertical furnaces (e.g., Johnson et al., 1995) and have resulted in an overestimation of trapping temperatures (a detailed discussion of this issue is presented in McNeill, 1997).

A further consequence of the lack of visual control is that trapping temperatures cannot be obtained independently but must instead be inferred from the chemical and/or phase compositions of the melt inclusion after an experiment. In other words, the melt inclusions are forced into reacting with their host phenocryst which leads, as discussed above, to irreversible changes in inclusion composition and the loss of information about possible re-equilibration during natural cooling.

In contrast, homogenisation experiments performed under visual control will yield an independent estimate of the trapping temperature. Models of mineral-melt equilibrium can then be used to assess whether the composition of the homogenised melt inclusion is in equilibrium with its host at the conditions of the experiment. If they are in equilibrium, then the temperature of homogenisation is the true crystallisation temperature of the phenocryst as re-equilibration was prevented during the experiment.

Potentially, the trapped melt composition and trapping temperature may also be reconstructed from the composition of the residual melt (i.e., glass) inside inclusions using numerical modelling (e.g. Sobolev and Shimizu, 1993; Danyushevsky et al., 2000a; Gaetani and Watson, 2000). However, today this approach is accurate for olivine-hosted melt inclusions only, and the results are strongly dependent on the extent of mass exchange between the melt inclusion and its host and/or outside magma after trapping, and require knowledge of the oxidation state and volatile contents of the melt.

\section{Estimation of parental magma $\mathrm{H}_{2} \mathrm{O}$ contents using melt inclusions}

Melt inclusions in phenocrysts from mantlederived magmas have been recognised as a useful tool for studies of volatile contents of primary melts (e.g., Roedder, 1979; Metrich and Clocchiatti, 1989; Sobolev and Danyushevsky, 1994; Sobolev and Chaussidon, 1996; Sisson and Layne, 1993; Sisson and Bronto, 1998; Hauri, 2002). Isolated by the host at relatively high pressure, melt inclusions may preserve original, or less degassed, volatile contents when compared to the erupted magmas (e.g., Sobolev and Chaussidon, 1996; Sobolev, 1996). When efficient quenching during eruption converts the residual melt inside inclusions into glass with no shrinkage/ fluid bubble, volatile contents can be measured without experimental reheating. If a shrinkage bubble is present in a glassy inclusion, an estimation of the volatile content is also possible, but the amount of volatiles in the bubble should be measured or calculated and added to the total volatile content (e.g. Sobolev et al., 1990; Anderson and Brown, 1993). However, efficient quenching is usually limited to samples from sea floor eruptions of relatively $\mathrm{H}_{2} \mathrm{O}-$ poor magmas, and in general, experimental homogenisation of melt inclusions is required to recover trapped volatile contents.

\section{1. $\mathrm{H}_{2} \mathrm{O}$ loss during experimental reheating of melt inclusions}

During reheating experiments, $\mathrm{H}_{2} \mathrm{O}$ can be lost from melt inclusions by dissociation and hydrogen diffusion through the host crystal (Roedder, 1979; Sobolev et al., 1983; Sobolev and Danyushevsky, 1994). Diffusion occurs because experiments are performed in an inert atmosphere (to prevent oxidation at high temperatures) at a low hydrogen fugacity (to prevent reaction with the platinum heater). The relatively high pressures inside melt inclusions at high temperature (see above) results in a higher hydrogen fugacity within inclusions than in the inert atmosphere around the crystal even when the inclusions have low $\mathrm{H}_{2} \mathrm{O}$ contents.

Sobolev et al. (1983) showed that during experiments with $\mathrm{H}_{2} \mathrm{O}$-bearing melt inclusions, a continuous increase in homogenisation temperature occurs when 
an inclusion is kept at high temperatures $\left(>1100{ }^{\circ} \mathrm{C}\right)$. This process is often accompanied by precipitation of magnetite inside an inclusion as described by the reaction:

$2 \mathrm{H}_{2} \mathrm{O}_{\text {melt }}+6 \mathrm{FeO}_{\text {melt }}=2 \mathrm{H}_{2} \uparrow+2 \mathrm{Fe}_{3} \mathrm{O}_{4}$

or at temperatures higher than magnetite stability,

$\mathrm{H}_{2} \mathrm{O}_{\text {melt }}+2 \mathrm{FeO}_{\text {melt }}=\mathrm{H}_{2} \uparrow+\mathrm{Fe}_{2} \mathrm{O}_{3 \text { melt }}$.

These reactions are limited by the ability of the melt to oxidise, and as the main component of natural melts that can be oxidised is $\mathrm{Fe}^{2+}$, the maximum amount of $\mathrm{H}_{2} \mathrm{O}$ that may dissociate can be calculated:

$\mathrm{H}_{2} \mathrm{O}($ wt. $\%)=0.125 * \mathrm{C}_{(\mathrm{FeO})}$,

where $\mathrm{C}_{(\mathrm{FeO})}=$ wt.\% FeO in the melt. For basaltic melts, the maximum amount of "lost" $\mathrm{H}_{2} \mathrm{O}$ is therefore $<1$ wt. $\%$.

When the host mineral contains $\mathrm{Fe}^{2+}$, it may potentially diffuse to the oxidised inclusion causing further dissociation of $\mathrm{H}_{2} \mathrm{O}$ in excess of the amount predicted from Eq. (3). At temperatures higher than magnetite stability, this will result in an artificially high total $\mathrm{Fe}$ content of the inclusion (Sobolev, unpublished data). In some cases, hydrogen diffusion can cause oxidation not only of the melt inclusion but also of the host phenocryst (Roedder, 1979). These cases of extreme oxidation are readily detectable when inclusions are examined under the microscope and can be easily avoided.

The dissociation of $\mathrm{H}_{2} \mathrm{O}$ in a melt inclusion increases the experimental homogenisation temperature in two different ways (Sobolev and Danyushevsky, 1994). First, the volume of melt is reduced due to loss of a component with large molar volume, thus decreasing pressure inside the melt inclusion, and second, the increase in the melting temperature of crystalline phases inside the melt inclusion. As discussed by Sobolev and Danyushevsky (1994), the effect of the reduction in melt volume is significant at low pressures $(<2 \mathrm{kbar})$ and at high temperatures $\left(>1100{ }^{\circ} \mathrm{C}\right)$ and can lead to a dramatic increase in homogenisation temperature. For small inclusions $(\sim 20 \mu \mathrm{m})$ the homogenisation temperature may increase by $150{ }^{\circ} \mathrm{C}$ during the first few minutes of an experiment (Fig. 3b). At higher pressures, this effect decreases, due to the volume reduction of $\mathrm{H}_{2} \mathrm{O}$ in melt, and the second factor dominates. This latter factor is pressure-independent but is a function of the composition of the host mineral and the total amount of $\mathrm{H}_{2} \mathrm{O}$ in the melt inclusion. If all the $\mathrm{Fe}$ in an olivine-hosted inclusion is oxidised (i.e., $\sim 1 \mathrm{wt} . \%$ $\mathrm{H}_{2} \mathrm{O}$ dissociates, Eq. (3)), and the initial $\mathrm{H}_{2} \mathrm{O}$ content of the inclusion was 1 or $3 \mathrm{wt} . \%$, then the effect will be to increase the homogenisation temperature by $\sim 75$ or $\sim 15^{\circ} \mathrm{C}$, respectively (Falloon and Danyushevsky, 2000). The effect on plagioclase is expected to be significantly larger (Danyushevsky, in press).

As homogenisation temperature is highly sensitive to dissociation of $\mathrm{H}_{2} \mathrm{O}$, determining crystallisation temperatures from homogenisation experiments on $\mathrm{H}_{2} \mathrm{O}$-bearing melts is relatively difficult. However, several experimental studies (e.g., Sobolev et al., 1990; Sobolev and Danyushevsky, 1994) have shown that the use of heating rates, established from kinetic experiments, and optimal inclusion sizes, as discussed below, makes it possible to establish the temperature of crystallisation and the trapped melt composition with an accuracy close to that obtained for "dry" melts.

For each sample, the effect of $\mathrm{H}_{2} \mathrm{O}$ dissociation on the homogenisation temperature can be estimated using kinetic experiments (Fig. 3b). An inclusion is heated rapidly (e.g., $100{ }^{\circ} \mathrm{C} / \mathrm{min}$ ) from $1100{ }^{\circ} \mathrm{C}$ until homogenisation is achieved. The temperature is then decreased to $1150-1200{ }^{\circ} \mathrm{C}$ and held for $15-30 \mathrm{~min}$. The temperature is then decreased to $1100{ }^{\circ} \mathrm{C}$ and heating is repeated at the initial rate until homogenisation occurs. These steps are repeated until the homogenisation temperature becomes asymptotic (Fig. 3b). The effect of $\mathrm{H}_{2} \mathrm{O}$ dissociation is clearly less for larger inclusions, and in general, inclusions as large as possible should be used for homogenisation experiments with $\mathrm{H}_{2} \mathrm{O}$-bearing magmas. As the lower viscosity of $\mathrm{H}_{2} \mathrm{O}$-bearing melts results in significantly faster kinetics of melting (Sobolev and Danyushevsky, 1994), the effect of $\mathrm{H}_{2} \mathrm{O}$ dissociation on homogenisation temperature completely overrides the effect of melting rates inside the inclusions. A summary of appropriate experimentally determined heating rates for $\mathrm{H}_{2} \mathrm{O}$-bearing magmas is presented in Table 1 . In general, melt inclusions from $\mathrm{H}_{2} \mathrm{O}$-bearing magmas should be kept at high temperatures for very short times (in order of minutes). 


\subsection{Changes of initial $\mathrm{H}_{2} \mathrm{O}$ contents of melt inclusions after trapping and prior to natural quenching}

Diffusion of hydrogen can affect $\mathrm{H}_{2} \mathrm{O}$ contents of melt inclusions not only during experimental reheating but also in nature, both before and during eruption, a result of the differing hydrogen fugacity inside inclusions and in the surrounding magma.

As decreasing temperature causes crystallisation of melt inclusions, it also results in decreasing pressure inside the inclusions, because the liquidus minerals of basaltic melts (olivine, pyroxene and plagioclase) are denser than the melt (Niu and Batiza, 1991; Lange and Carmichael, 1987). Cooling in a magma chamber after trapping may thus result in a lower hydrogen fugacity inside inclusions and diffusion of hydrogen into the inclusions from the host magma, thus increasing the $\mathrm{H}_{2} \mathrm{O}$ content of melt inclusions following the reverse of reaction (2). This reaction is limited by the ability of the melt to be reduced, and as $\mathrm{Fe}^{3+}$ is the main component of natural melts that can be reduced, the maximum amount of $\mathrm{H}_{2} \mathrm{O}$ that may be formed is:

$$
\Delta \mathrm{H}_{2} \mathrm{O}(\text { wt. } \%)=0.113 * \mathrm{Fe}_{2} \mathrm{O}_{3} .
$$

As the $\mathrm{Fe}_{2} \mathrm{O}_{3}$ contents of natural magmas rarely exceed 1 wt.\%, the amount of 'gained' $\mathrm{H}_{2} \mathrm{O}$ is petrologically negligible.

Alternatively, if a magma rises without substantial cooling after an inclusion was trapped, then the pressure inside the inclusion will remain close to the pressure of trapping (as no significant crystallisation will occur). However, as the pressure on the host magma decreases, there will be a higher hydrogen activity within inclusions than in the host magma, a situation similar to that which occurs during homogenisation experiments (see above). In this case, hydrogen may diffuse out of the melt inclusions causing $\mathrm{H}_{2} \mathrm{O}$ dissociation following reactions (1) or (2). A clear indication of this process is the appearance of magnetite 'dust' in some naturally quenched inclusions (Verbeeten, 1996). When magnetite 'dust' is not observed in inclusions, the loss of $\mathrm{H}_{2} \mathrm{O}$ can be assumed to be negligible as magnetite stability is very sensitive to melt $\mathrm{Fe}_{2} \mathrm{O}_{3}$ content (Ariskin and Barmina, 1999), and the appearance of the magnetite 'dust' has been observed in homogenisation experiments with virtually anhydrous $\left(\mathrm{H}_{2} \mathrm{O} \sim 0.1\right.$ wt. $\left.\%\right)$ reduced ( $\mathrm{fO}_{2}$ $<$ quartz-fayalite-magnetite buffer) melt inclusions in MORB phenocrysts (Sobolev et al., 1988).

Under certain circumstances, e.g., when melt inclusions in olivine have undergone significant $\mathrm{Fe}$ loss resulting from prolonged cooling (as discussed by Danyushevsky et al., 2000a), magnetite "dust" may be prevented from forming due to low melt $\mathrm{Fe}$ contents, even when a significant amount of $\mathrm{H}_{2} \mathrm{O}$ has been dissociated. In such a case, it may therefore not be obvious that $\mathrm{H}_{2} \mathrm{O}$ has been lost. However, the $\mathrm{D} / \mathrm{H}$ values of melt inclusions are a potential indicator of hydrogen diffusion, as hydrogen diffuses faster than deuterium, and therefore higher $\mathrm{D} / \mathrm{H}$ values may indicate $\mathrm{H}_{2} \mathrm{O}$ loss (Hauri, 2002). In general, two characteristics of inclusions that have undergone extensive Fe loss make it unlikely that significant $\mathrm{H}_{2} \mathrm{O}$ will also have been lost. First, the low Fe contents (in some cases as low as 3 wt.\%; Danyushevsky et al., 2000a) will reduce the oxidation potential of the inclusion; and second, prolonged cooling will lead to extensive crystallisation of the inclusion, reducing the pressure inside the inclusion and making $\mathrm{H}_{2} \mathrm{O}$ gain more likely (as discussed above) than $\mathrm{H}_{2} \mathrm{O}$ loss.

Qin et al. (1992) demonstrated that on geological time scales, $\mathrm{H}_{2} \mathrm{O}$ can be lost from inclusions by diffusion of molecular $\mathrm{H}_{2} \mathrm{O}$ through the host crystal. Diffusion can happen when the phenocryst which trapped the inclusion at high pressures is retained in a low-pressure magma chamber as the host magma degasses. This process is difficult to detect as it does not result in oxidation and the formation of magnetite in melt inclusions. However, Qin et al. (1992) also demonstrated that the diffusion of $\mathrm{H}_{2} \mathrm{O}$ is significantly slower than the diffusion of major elements in the host phenocryst. Therefore, any significant loss of $\mathrm{H}_{2} \mathrm{O}$ must be preceded by the re-equilibration of the host phenocryst with the more evolved, degassed magma. However, re-equilibration of phenocrysts is usually not observed in primitive mantle-derived magmas, as numerous studies have reported original primitive phenocryst compositions (e.g., Eggins, 1993, their Table 10; Sobolev, 1996; Sobolev and Chaussidon, 1996). Molecular $\mathrm{H}_{2} \mathrm{O}$ diffusion is more likely to occur in melt inclusions of more evolved andesitedacite-rhyolite melts where the long residence time of phenocrysts in magma chambers is well-documented (e.g., Christensen and DePaolo, 1993). 
It is therefore unlikely that any petrologically significant amount of $\mathrm{H}_{2} \mathrm{O}$ will have been lost or gained by melt inclusions, after trapping and prior to natural quenching, if magnetite 'dust' is not present in the naturally quenched inclusion. The general representativeness of the $\mathrm{H}_{2} \mathrm{O}$ contents of melt inclusions that were homogenised using optimal experimental conditions can be demonstrated by their correlation with other petrological parameters (e.g., Danyushevsky et al., 1995, 1997; Sobolev and Chaussidon, 1996). However, some of the processes described above can lead to geochemically significant changes in the $\mathrm{H}_{2} \mathrm{O}$ content of melt inclusions, i.e., the $\mathrm{H}_{2} \mathrm{O}$ / (incompatible element) values of melt inclusions can be significantly different from those of the trapped liquid. For example, discrepancies between the $\mathrm{H}_{2} \mathrm{O}$ / $\mathrm{K}_{2} \mathrm{O}$ values of melt inclusions and pillow-rim glasses in depleted MORB from the Mid-Atlantic Ridge have been reported by Sobolev (1996) and Kamenetsky et al. (1998).

\subsection{General aspects of melt inclusion studies aimed at recovering $\mathrm{H}_{2} \mathrm{O}$ content of primary mantle-derived magmas}

Consider a melt formed in the mantle under $\mathrm{H}_{2} \mathrm{O}$ undersaturated conditions (Fig. 5, point 1). The slowest possible thermodynamic ascent rate for this melt that will not cause compositional changes is defined by the pressure dependence of the olivine liquidus ( $\sim 5{ }^{\circ} \mathrm{C} / \mathrm{kbar}$, Ford et al., 1983; path 1-2, Fig. 5). If the rate of ascent is thermodynamically slower (i.e., it cools faster than $5{ }^{\circ} \mathrm{C} / \mathrm{kbar}$ ), the melt will start to crystallise. Point 2 (Fig. 5) indicates the minimum depth that this melt can reach without changing its composition, as at this pressure, the melt will be $\mathrm{H}_{2} \mathrm{O}$ saturated and any further ascent will cause degassing and crystallisation. However, the actual ascent rates of mantle-derived magmas are believed to be $\sim 3{ }^{\circ} \mathrm{C} /$ kbar (Nisbet, 1982) corresponding to the adiabat of a high Mg liquid (path 1-3, Fig. 5), and point 3 represents the minimum depth that such a melt can reach without degassing. The grey envelope $1-2-3$ (Fig. 5) thus represents the $P-T$ range where a melt can exist without any changes in its initial composition. Note that at any temperature above line 1-2 on Fig. 5, the melt is overheated, i.e., its temperature is higher than its liquidus temperature for a given pressure, and

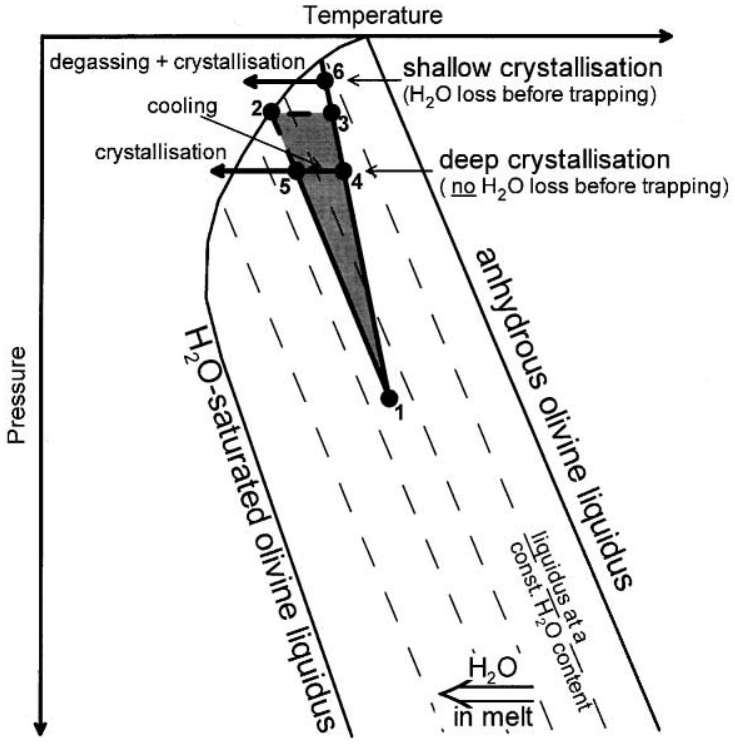

Fig. 5. Diagram illustrating the two end-member cases of crystallisation of a melt formed in the mantle under $\mathrm{H}_{2} \mathrm{O}$ undersaturated conditions. The effect of $\mathrm{H}_{2} \mathrm{O}$ on olivine liquidus is from Falloon and Danyushevsky (2000) and references therein. 1 Represents the point of melt generation in the mantle; path 1-2 melt ascent along olivine liquidus ( $\left.\sim 5{ }^{\circ} \mathrm{C} / \mathrm{kbar}\right)$; path $1-6-$ melt ascent along an adiabat $\left(\sim 3{ }^{\circ} \mathrm{C} / \mathrm{kbar}\right)$; grey envelope $1-2-3-$ the $P-T$ range where the melt can exist without changing its initial composition including its $\mathrm{H}_{2} \mathrm{O}$ content; level 2-3-the minimum depth which the melt can reach without degassing; path 4-5-a case of deep crystallisation that proceeds initially without degassing at a depth where the melt is undersaturated in $\mathrm{H}_{2} \mathrm{O}$; path 6 - a case of shallow crystallisation that commences after initial degassing. See text for discussion.

cooling at a constant pressure will not cause immediate crystallisation.

Two end-member cases of crystallisation of a mantle-derived melt are shown on Fig. 5. Deep crystallisation (point 4, Fig. 5) refer to crystallisation at pressures higher than the saturation pressure for the initial melt $\mathrm{H}_{2} \mathrm{O}$ content (point 2, Fig. 5), whereas shallow crystallisation occurs at pressures less than the saturation pressure for the initial $\mathrm{H}_{2} \mathrm{O}$ content (point 6, Fig. 5).

In the case of deep crystallisation, when melt ascent is interrupted (point 4, Fig. 5), cooling occurs at a constant pressure and crystallisation will begin when the melt reaches its liquidus (point 5, Fig. 5). As crystallisation proceeds under $\mathrm{H}_{2} \mathrm{O}$-undersaturated conditions, no $\mathrm{H}_{2} \mathrm{O}$ loss will occur along path $4-5$ 
(Fig. 5) and a melt inclusion trapped by the first most magnesian olivine phenocryst that crystallises will preserve the $\mathrm{H}_{2} \mathrm{O}$ content of the primary melt (point 1, Fig. 5). If the first liquidus olivine did not trap any melt inclusions, or was not recovered in the studied samples, the $\mathrm{H}_{2} \mathrm{O}$ content of the primary melt can be confidently estimated from melt inclusions in near liquidus olivine phenocrysts (formed at temperatures below point 5 along path $4-5$, Fig. 5 ). This is because the rate of olivine crystallisation for high $\mathrm{Mg}$ melts is $\sim 1 \%$ per $8{ }^{\circ} \mathrm{C}$ temperature drop (Ford et al., 1983), and thus changes in melt $\mathrm{H}_{2} \mathrm{O}$ content caused by olivine-only crystallisation over $\sim 40{ }^{\circ} \mathrm{C}(\sim 5 \%)$ are within analytical uncertainties.

In the second case, i.e., shallow crystallisation at pressures less than the saturation pressure at the initial $\mathrm{H}_{2} \mathrm{O}$ content (point 6, Fig. 5), adiabatic ascent over $10 \mathrm{kbar}$ (for example) results in overheating of the melt by $\sim 20{ }^{\circ} \mathrm{C}$ (see above). If such a melt becomes $\mathrm{H}_{2} \mathrm{O}$ saturated, degassing will not cause immediate crystallisation and some $\mathrm{H}_{2} \mathrm{O}$ may be lost before crystallisation begins. Due to the non-linear effect of $\mathrm{H}_{2} \mathrm{O}$ on olivine liquidus temperature (Falloon and Danyushevsky, 2000), the amount of lost $\mathrm{H}_{2} \mathrm{O}$ will depend on the initial $\mathrm{H}_{2} \mathrm{O}$ content of the melt. For example, if the initial $\mathrm{H}_{2} \mathrm{O}$ content was 1 wt. $\%$, then $20{ }^{\circ} \mathrm{C}$ overheating will result in 0.6 wt.\% $\mathrm{H}_{2} \mathrm{O}$ loss prior to crystallisation. However, if the initial melt $\mathrm{H}_{2} \mathrm{O}$ content was 4 wt.\%, the same overheating will result in 1.6 wt. $\% \mathrm{H}_{2} \mathrm{O}$ loss (see Falloon and Danyushevsky, 2000). As low-pressure crystallisation is often accompanied by degassing (i.e., degassing does not stop when crystallisation begins; e.g., Danyushevsky et al., 1995), it is vitally important to identify the most magnesian olivine that crystallised from the melt and to analyse the $\mathrm{H}_{2} \mathrm{O}$ contents of its melt inclusions. In contrast to the case of deep crystallisation, a failure to identify the composition of the first liquidus olivine can lead to a substantial underestimation of the initial melt $\mathrm{H}_{2} \mathrm{O}$ content. If the $\mathrm{H}_{2} \mathrm{O}$ content at the onset of crystallisation is known, a correction for degassing before crystallisation began can be estimated from (1) the major element composition of the primary melt, to determine the pressure of melting (Falloon and Danyushevsky, 2000), and (2) an assumed ascent rate of the melt from the depth of melting to the depth of crystallisation, to estimate overheating.
The pressure of crystallisation can be estimated if both the $\mathrm{H}_{2} \mathrm{O}$ and $\mathrm{CO}_{2}$ contents of the melt are known (Dixon et al., 1995). For a fluid-saturated melt, increasing $\mathrm{CO}_{2}$ content, at a given $\mathrm{H}_{2} \mathrm{O}$ content, corresponds to increasing pressure. Alternatively, crystallisation pressure can be estimated from the composition and/or density of primary fluid inclusions in phenocrysts (e.g., Roedder, 1984). In general, a high proportion of $\mathrm{H}_{2} \mathrm{O}$ in the fluid indicates lowpressure crystallisation, whereas a high proportion of $\mathrm{CO}_{2}$ indicates high-pressure crystallisation (see Dixon et al., 1995 for the effect of $\mathrm{CO}_{2}$ on $\mathrm{H}_{2} \mathrm{O}$ solubility).

\section{Effect of Fe loss by melt inclusions in olivine phenocrysts on sulphur solubility and oxidation state}

As discussed above, the re-equilibration of melt inclusions with their host during natural cooling results in changes in inclusion compositions. An example of such re-equilibration is the Fe loss suffered by some melt inclusions in olivine (e.g., Sobolev, 1983; Sobolev and Danyushevsky, 1994), described in detail by Danyushevsky et al. (2000a). In brief, most melt inclusions in magnesian olivine phenocrysts (generally $>\mathrm{Fo}_{85}$ ) from subduction-related and within-plate lavas have a significantly lower $\mathrm{FeO}$ content and a higher

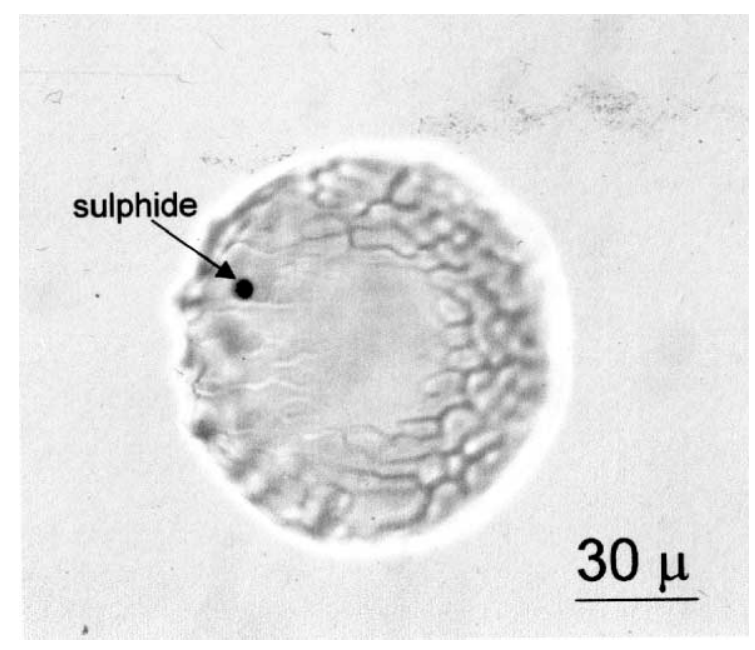

Fig. 6. Sulphide globule in a homogenised melt inclusion in an olivine phenocryst from MORB (southern Mid-Atlantic Ridge, Kamenetsky, unpublished). 
$\mathrm{MgO}$ content than the originally trapped melt. Low $\mathrm{FeO}$ contents are less common in MORB and back-arc basin basalts.

Many homogenised melt inclusions in OIB and MORB olivine phenocrysts, which have experienced Fe loss, contain small sulphide globules (Fig. 6), the size of which is proportional to the size of the melt inclusions in a given sample (Gurenko et al., 1987; Metrich et al., 1999). In some cases, such globules are observed in naturally quenched melt inclusions (Sobolev, unpublished data). Despite clear indications that the sulphide is a daughter phase (e.g., proportionality of size), the globules will not melt even after homogenisation of an inclusion (i.e., melting of microlites and dissolution of the gas/shrinkage bubble).
The sulphide globules are a consequence of $\mathrm{Fe}$ loss, rather than indicating sulphide saturation of the trapped melt, or changes in the $\mathrm{fO}_{2}$ or $\mathrm{H}_{2} \mathrm{O}$ content after trapping (Gurenko et al., 1987; Metrich et al., 1999). As sulphur solubility is strongly dependent on the Fe content of a melt (Wallace and Carmichael, 1992); decreasing the $\mathrm{Fe}$ content of a melt inclusion may lead to sulphur saturation and exsolution of the sulphide globule. This also results in artificially low melt sulphur contents within such inclusions.

Moreover, as an olivine is unlikely to buffer the oxidation state of any melt inclusion it hosts (as indicated by commonly observed $\mathrm{H}_{2} \mathrm{O}$ loss from inclusions, see above), Fe loss will lead to a higher oxidation state (i.e., higher $\mathrm{Fe}^{3+} / \mathrm{Fe}^{2+}$ values) for

\section{a}

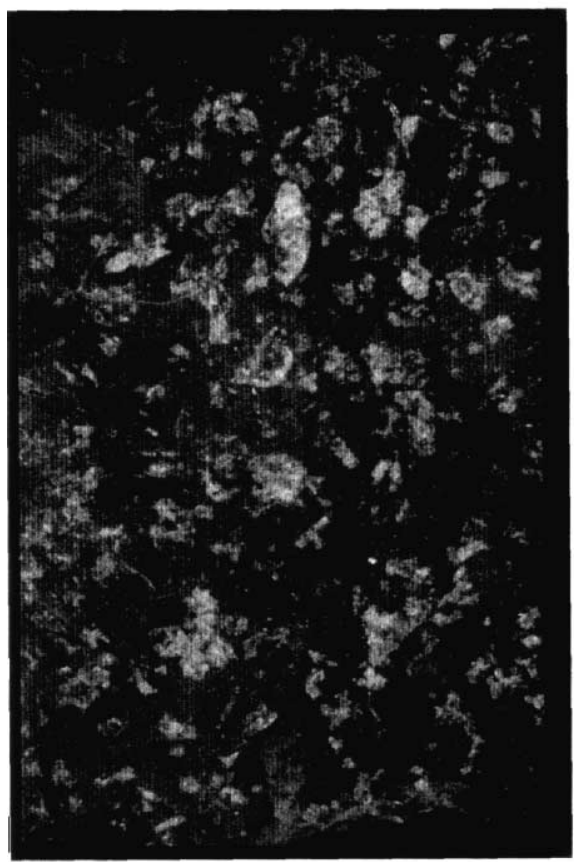

b

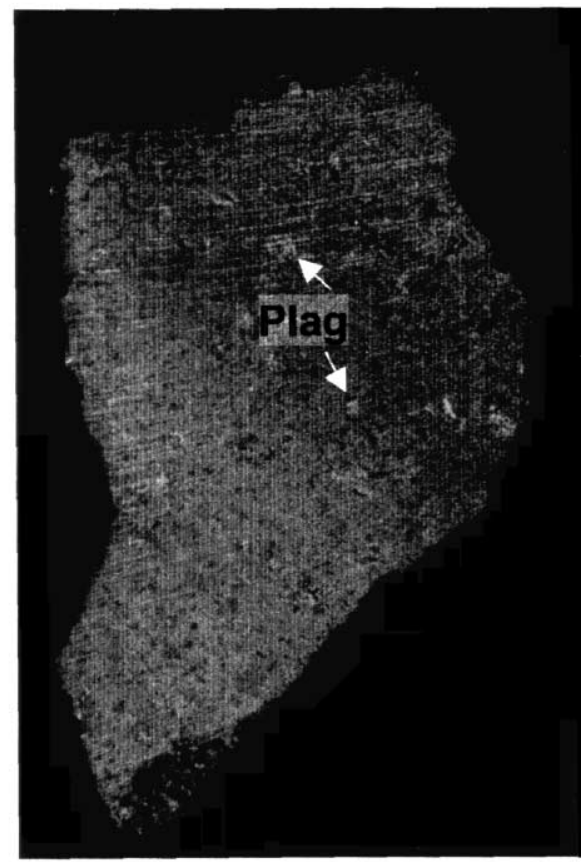

\section{$2 \mathrm{~cm}$}

Fig. 7. (a) A typical example of a plagioclase-phyric MORB (sample MW8801-D5-2, Australia-Antarctic Discordance, Southern Ocean). Note obvious accumulation of plagioclase, i.e. the composition of this sample does not represent the melt composition being enriched in plagioclase components. (b) Sample 5-2-5 from ODP Hole 896A. Note a small size of plagioclase phenocrysts and the lack of any significant plagioclase accumulation. See text for discussion. 
the melt inclusions. This will in turn affect the oxidation state of sulphur in inclusions, and therefore, the $\mathrm{S}^{2-} / \mathrm{S}^{6+}$ values of melt inclusions in olivine, for which the extent of $\mathrm{Fe}$ loss has not been constrained (e.g., Metrich and Clocchiatti, 1996; Gurenko and Schmincke, 2000), should be treated with care.

Another consequence of $\mathrm{Fe}$ loss is reported by Sobolev (1983). Since Fe/Mg values of the affected inclusions are significantly lower, this increases stability of $\mathrm{Fe}-\mathrm{Mg}$ daughter phases inside inclusions. Clinopyroxene in melt inclusions in olivine from Siberian meimechites melts at $100{ }^{\circ} \mathrm{C}$ higher temperatures than is observed in the macro-system. Thus, melting temperatures of clinopyroxene inside inclusions affected by $\mathrm{Fe}$ loss cannot be used as an indicator of the cotectic relationships in the macro system.

\section{Some examples of poorly understood reequilibration processes or trapping of non-representative compositions}

A number of studies of plagioclase phenocrysts from MORB have described melt inclusion compositions that are more primitive (i.e., more $\mathrm{MgO}$-rich) than pillow-rim glasses from the studied area (Sobolev et al., 1988; Sinton et al., 1993; Nielsen et al., 1995; Sours-Page et al., 1999). These studies report a number of features (e.g., a range of $\mathrm{TiO}_{2}$ contents at a given $\mathrm{MgO}$ content) that are not seen in more evolved pillow-rim glasses. It is possible to reconcile these observations by invoking intensive mixing of a variety of primitive magmas prior to the eruption that transported the plagioclase phenocrysts to the surface

Fig. 8. Compositions of pillow-rim glasses from ODP Hole 896A (McNeill and Danyushevsky, 1996). Glasses from samples used in the melt inclusion study are identified on the lower plot. Solid lines show a fractionation trend calculated from the average most primitive glass composition. Calculations were carried out using the model of Danyushevsky (in press) assuming crystallisation pressure of $0.05 \mathrm{GPa}$, melt $\mathrm{Fe}^{2+} / \mathrm{Fe}^{3+}$ value of 11 , and the olivine + plagioclase cotectic nature of the starting composition. At these conditions, clinopyroxene appears on the liquidus at $~ 8.6 \mathrm{wt} . \%$ $\mathrm{MgO}$ as can be seen by the inflection on the trend. The figure demonstrates that glass compositions from this Hole closely follow an olivine + plagioclase \pm clinopyroxene fractionation trend. See text for discussion.

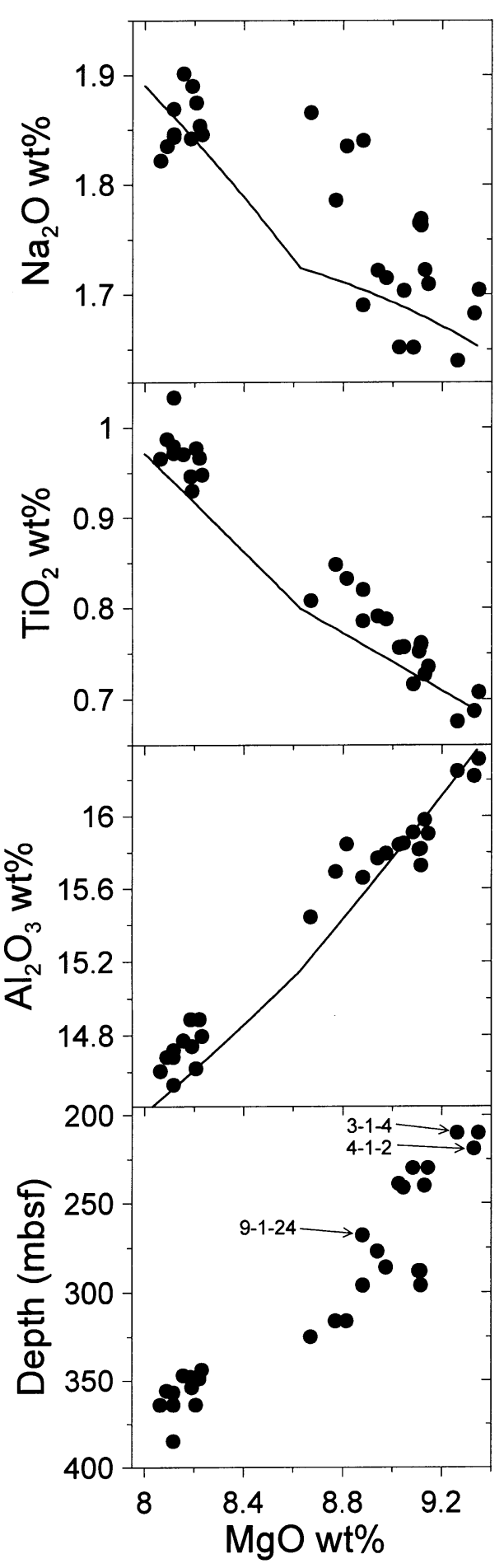


and produced the more evolved pillow-rim glasses. However, it is important to consider if the studied melt inclusion compositions are representative of the melt composition at the time of trapping. We can address this problem by studying melt inclusions with compositions within the range covered by pillow-rim glasses (McNeill and Danyushevsky, 1996). In a suitable suite of samples, the compositions of pillow-rim glasses must form a well-defined liquid line of descent (to enable comparison with melt inclusion compositions), and the samples must not have undergone extensive plagioclase accumulation. The latter is important as, if accumulation had occurred (Fig. 7a), it can be argued that phenocrysts present in the rock crystallised from a different melt than that represented by the pillow-rim glasses and thus the compositions of melt inclusions will not match the compositions of the glasses.

The criteria outlined above are satisfied by MORB samples from ODP Hole 896A (McNeill and Danyushevsky, 1996). Samples from this hole underwent no plagioclase accumulation (Fig. 7b) and it cannot be argued that phenocrysts found in these rocks crystallised from a different melt. The compositions of glasses recovered from 200 to 400 mbsf follow a fractionation trend formed by low-pressure cotectic crystallisation of olivine and plagioclase with clinopyroxene joining the liquidus at $\sim 8.5$ wt.\% $\mathrm{MgO}$ (Fig. 8 ).

Homogenisation experiments were carried out with melt inclusions in plagioclase phenocrysts from three samples (Fig. 9) and yielded homogenisation temperatures in the range $1195-1215{ }^{\circ} \mathrm{C}$ (see McNeill and Danyushevsky, 1996 and McNeill, 1997 for a detailed description of experimental procedures and results). As the $\mathrm{H}_{2} \mathrm{O}$ contents of these glasses are known (McNeill and Danyushevsky, 1996), their crystallisation temperature can be accurately estimated assuming olivine and plagioclase saturation (Danyushevsky, in press). Calculated olivine- and plagioclase-melt equilibrium temperatures, for the most evolved and most

Fig. 9. Comparison of compositions of homogenised melt inclusions in plagioclase phenocrysts with glasses from MORB samples from ODP Hole 896A. Melt inclusions from different samples are shown with different symbols. Glasses from samples used in melt inclusion studies are identified on Fig. 8. Note the good correspondence between compositions of glasses and homogenised melt inclusions for $\mathrm{MgO}, \mathrm{CaO}, \mathrm{Al}_{2} \mathrm{O}_{3}$, and $\mathrm{Na}_{2} \mathrm{O}$. See text for discussion. primitive glasses range from 1182 to $1213{ }^{\circ} \mathrm{C}$ and from 1179 to $1217{ }^{\circ} \mathrm{C}$, respectively, consistent with the range of experimental homogenisation temperatures.

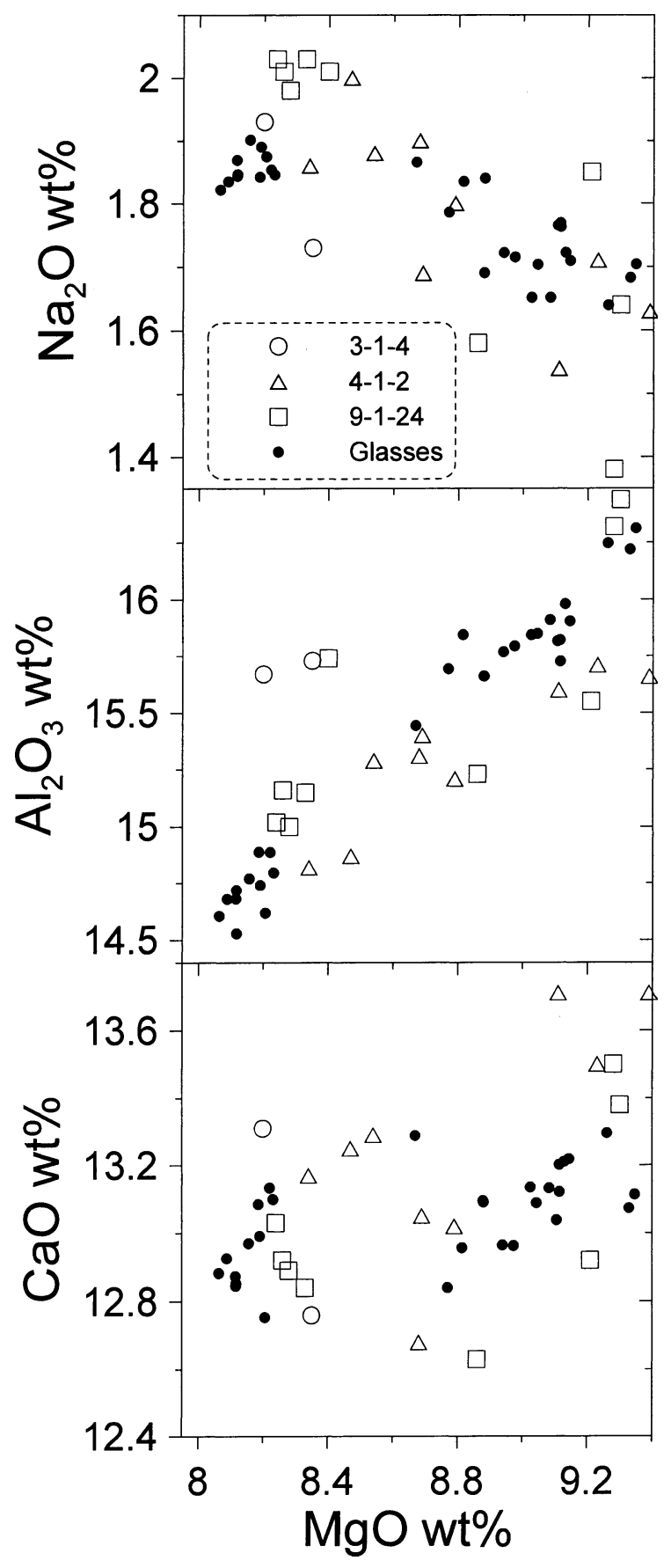


As can be expected, the $\mathrm{MgO}$ contents of the homogenised melt inclusions are similar to those of glasses, as are the $\mathrm{CaO}, \mathrm{Al}_{2} \mathrm{O}_{3}$, and $\mathrm{Na}_{2} \mathrm{O}$ contents (Fig. 9). There is also a good correlation between the $\mathrm{MgO}$ and $\mathrm{Na}_{2} \mathrm{O}$ contents of the melt inclusions and the compositions of their host plagioclase (Fig. 10).

All the foregoing observations indicate that plagioclase phenocrysts crystallised along the liquid line of descent represented by glasses, however, the $\mathrm{TiO}_{2}$ contents of the homogenised melt inclusions are systematically lower than those along the glass trend, as are their $\mathrm{FeO}^{*}$ contents (Fig. 11). The lower $\mathrm{TiO}_{2}$ and $\mathrm{FeO}^{*}$ content of the melt inclusions are matched by higher $\mathrm{SiO}_{2}$ contents (Fig. 11). These compositional variations do not result from processes occurring during the homogenisation experiments, as naturally quenched glassy melt inclusions in plagioclase phenocrysts from these samples also have low $\mathrm{TiO}_{2}$ contents (McNeill and Danyushevsky, 1996).

Anomalously low $\mathrm{TiO}_{2}$ and $\mathrm{FeO}^{*}$ contents of melt inclusions in plagioclase phenocrysts are a common feature of MORB. Plagioclase phenocrysts A27-PL8 from sample D9-1 (Gorda Ridge) contains several naturally quenched glassy melt inclusions (Table 2). The phenocryst is not zoned, as can be seen from the low standard deviation of the average host composition for seven melt inclusions (Table 2). The glass compositions have low $\mathrm{Al}_{2} \mathrm{O}_{3}$ and high $\mathrm{MgO}$ contents, a result of plagioclase crystallisation on the walls of the inclusion after trapping. The trapped liquid composition was therefore estimated by modelling the reverse of plagioclase crystallisation on the walls of the inclusions until the composition reached an olivine + plagioclase cotectic (see Danyushevsky et al., 2000a for methods used to calculate the reverse of crystallisation).

Plagioclase phenocryst A27-PL8 also hosts an inclusion of spinel that in turn contains melt inclusions. It is reasonable to assume that plagioclase and spinel crystallised from a single melt and thus melt inclusions in both minerals are expected to have the same composition. The average composition of the melt inclusions in spinel, corrected for $\mathrm{Cr}$ interference during microprobe analysis, is shown in the lower part of Table 2. The melt inclusions in plagioclase have substantially lower $\mathrm{TiO}_{2}$ contents than the inclusions in spinel, and also have lower $\mathrm{FeO}$ contents, however, the $\mathrm{MgO}, \mathrm{Na}_{2} \mathrm{O}, \mathrm{CaO}$ and $\mathrm{K}_{2} \mathrm{O}$ contents of inclusions

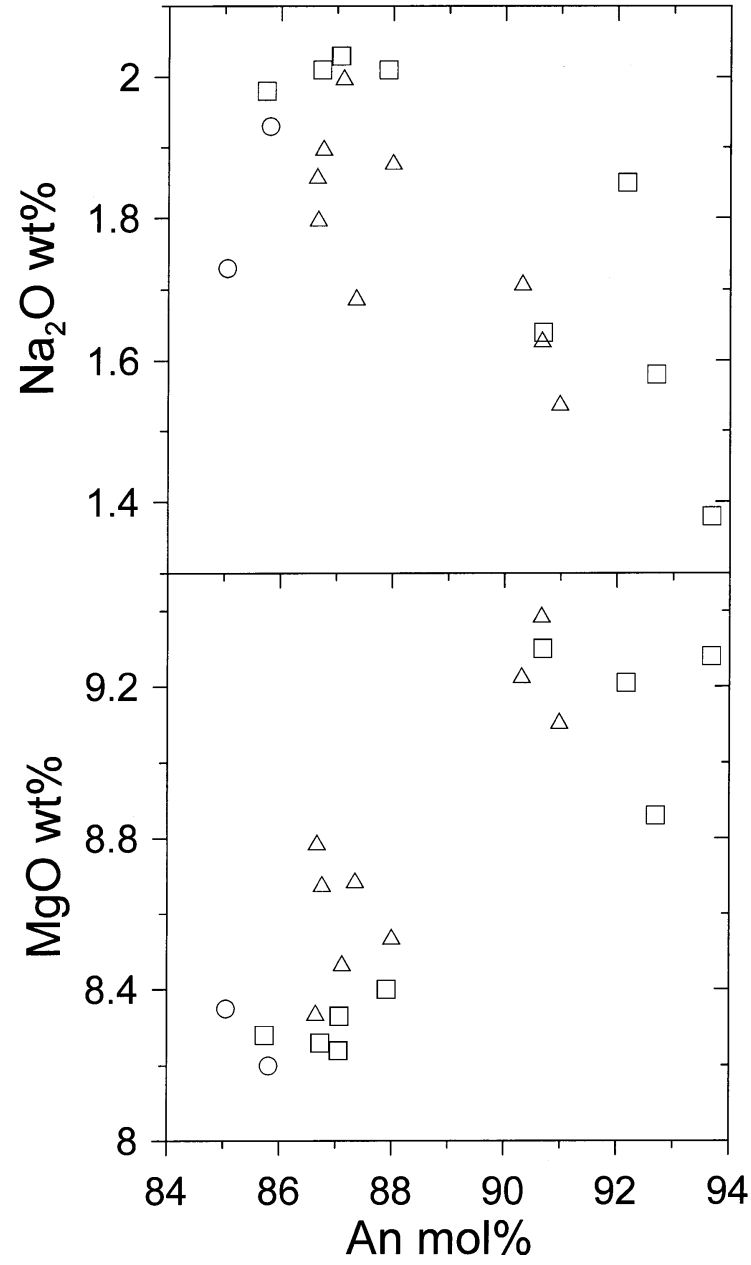

Fig. 10. Correlation between compositions of homogenised melt inclusions and their host plagioclase phenocrysts for samples from ODP Hole 896A. Melt inclusions from different samples are shown with different symbols. Symbols as on Fig. 9. Host plagioclase was analysed at $20-30 \mu \mathrm{m}$ from the inclusions. See text for discussion.

in both minerals are similar. The lower $\mathrm{Al}_{2} \mathrm{O}_{3}$ contents in inclusions in spinel most likely indicate re-equilibration of these inclusions with their host.

The pillow-rim glasses from Gorda Ridge samples are significantly more evolved than the compositions of melt inclusions in high-An plagioclase (Nielsen et al., 1995; McNeill, 1997)) and thus a direct comparison with the melt inclusions is not possible. However, if the sample D9-1 pillow-rim glass composition (Table 2) is recalculated along an olivine-plagioclase 
cotectic to an $\mathrm{MgO}$ content similar to that of melt inclusions, the $\mathrm{TiO}_{2}$ content of the recalculated glass is similar to that of the melt inclusions in spinel, but is

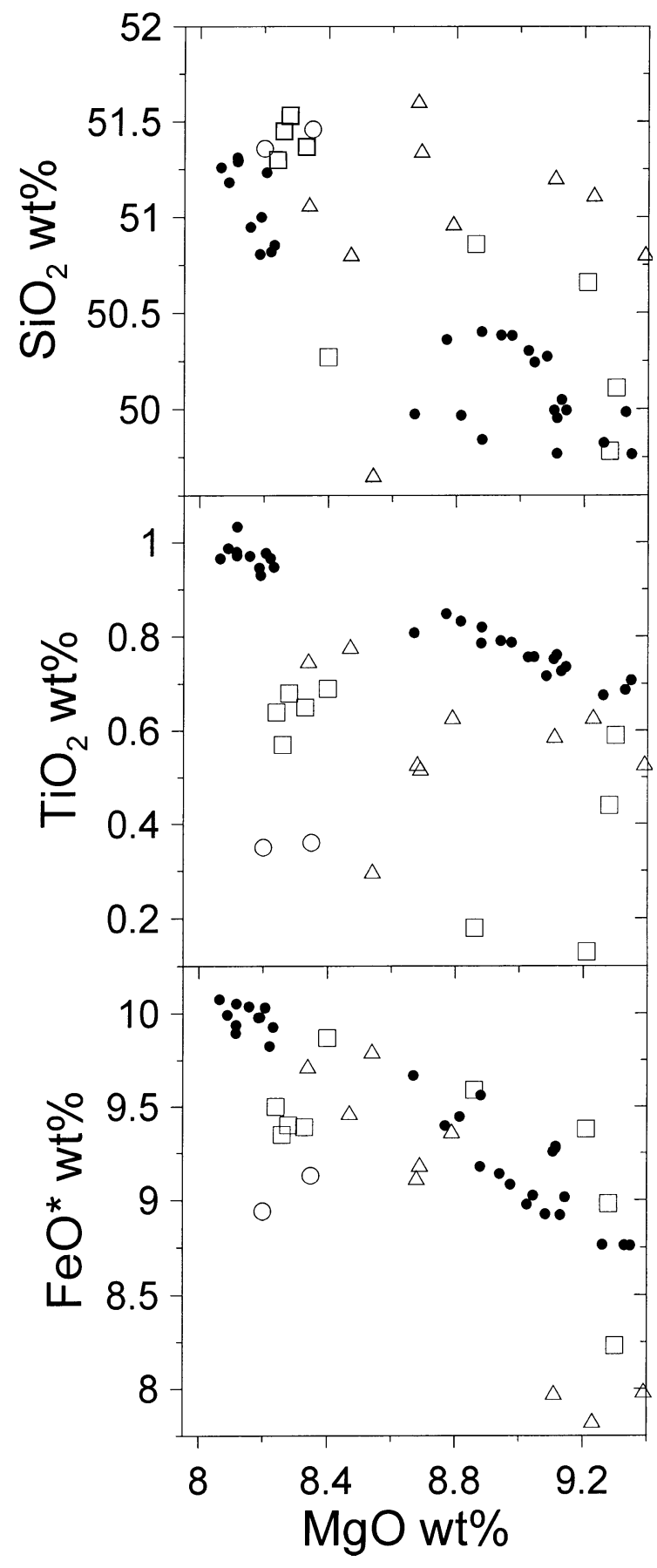

significantly higher than in the inclusions in plagioclase (see Danyushevsky et al., 2000b for the principles of modelling the reverse of cotectic crystallisation of olivine + plagioclase \pm clinopyroxene).

The two examples described above make us confident that low $\mathrm{Ti}$ and $\mathrm{Fe}$ and high $\mathrm{Si}$ contents of homogenised melt inclusions in plagioclase from MORB do not reflect the composition of the host magma and cannot be used to infer petrological processes. We see two possible explanations for these anomalies. Firstly, they may reflect a re-equilibration of the melt inclusions with their hosts during cooling and before eruption (similar to the Fe loss by inclusions in olivine, Danyushevsky et al., 2000a), whereby $\mathrm{Fe}$ and Ti diffuse from melt inclusions into the host plagioclase and Si diffuses from the host into the melt inclusions. At the moment, we are unable to provide either a reason or a direct evidence for such re-equilibration. However, an indirect evidence of lower Fe contents, than were trapped, in the homogenised melt inclusions is the common appearance of small sulphide globules, similar to those observed in inclusions in olivine (see Section 4 above). These globules are not observed in naturally quenched glassy melt inclusions and appear during the experiments at high temperatures. As in the case with melt inclusions in olivine, these globules do not disappear when melt inclusions homogenise. The absence of these globules in naturally quenched melt inclusions is explained by high $\mathrm{Fe}$ contents in the residual melt inside them, a result of plagioclase crystallisation on the walls of these inclusions. As MORB magmas are saturated in sulphur (Wallace and Carmichael, 1992), only a small decrease in melt Fe content (Fig. 11) is sufficient to form a sulphide globule.

An alternative explanation for the low Ti contents is provided by Michael et al. (2002) who suggested that melt inclusions are trapped by plagioclase in a continuous cycle of growth and dissolution, similar to

Fig. 11. Comparison of compositions of homogenised melt inclusions in plagioclase phenocrysts with glasses from MORB samples from ODP Hole 896A. Melt inclusions from different samples are shown with different symbols. Symbols as on Fig. 9. Glasses from samples used in melt inclusion studies are identified on Fig. 8. Note large differences between compositions of glasses and homogenised melt inclusions for $\mathrm{SiO}_{2}, \mathrm{TiO}_{2}$, and $\mathrm{FeO}^{*}$. See text for discussion. 
Table 2

Compositions of melt inclusions in plagioclase phenocrysts A27PL8 from MORB sample D9-1, Gorda Ridge

\begin{tabular}{|c|c|c|c|c|c|}
\hline & \multicolumn{2}{|c|}{$\begin{array}{l}\text { Naturally quenched } \\
\text { glassy inclusions in } \\
\text { plagioclase }\end{array}$} & \multicolumn{2}{|c|}{$\begin{array}{l}\text { Naturally quenched } \\
\text { glassy inclusions in } \\
\text { spinel included in } \\
\text { plagioclase }\end{array}$} & \multirow[t]{2}{*}{$\begin{array}{l}\text { Pillow- } \\
\text { rim glass } \\
\text { of sample } \\
\text { D9-1 }\end{array}$} \\
\hline & Average of 7 & S.D. & Average of 2 & S.D. & \\
\hline $\mathrm{SiO}_{2}$ & 50.64 & 0.15 & 49.44 & 0.01 & 50.94 \\
\hline $\mathrm{TiO}_{2}$ & 0.33 & 0.11 & 0.78 & 0.05 & 1.26 \\
\hline $\mathrm{Al}_{2} \mathrm{O}_{3}$ & 14.01 & 0.35 & 15.93 & 0.67 & 15.43 \\
\hline $\mathrm{FeO}^{*}$ & 8.42 & 0.30 & 8.18 & 0.55 & 9.53 \\
\hline $\mathrm{MnO}$ & 0.16 & 0.02 & 0.15 & 0.03 & 0.13 \\
\hline $\mathrm{MgO}$ & 11.96 & 0.45 & 9.99 & 0.43 & 8.17 \\
\hline $\mathrm{CaO}$ & 12.67 & 0.25 & 12.98 & 0.69 & 12.15 \\
\hline $\mathrm{Na}_{2} \mathrm{O}$ & 1.70 & 0.08 & 1.74 & 0.24 & 2.31 \\
\hline $\mathrm{K}_{2} \mathrm{O}$ & 0.03 & 0.01 & 0.03 & 0.01 & 0.06 \\
\hline $\mathrm{Cr}_{2} \mathrm{O}_{3}$ & 0.07 & 0.03 & 0.79 & 0.01 & 0.03 \\
\hline $\begin{array}{l}\text { Host An } \\
\mathrm{mol} \%\end{array}$ & 92.3 & 0.42 & 93.7 & & \\
\hline \multicolumn{6}{|c|}{ Compositions corrected for fractionation } \\
\hline $\mathrm{SiO}_{2}$ & 49.94 & 0.20 & 50.56 & 0.03 & 49.18 \\
\hline $\mathrm{TiO}_{2}$ & 0.27 & 0.09 & 0.79 & 0.05 & 0.86 \\
\hline $\mathrm{Al}_{2} \mathrm{O}_{3}$ & 17.65 & 0.44 & 15.50 & 0.68 & 18.15 \\
\hline $\mathrm{FeO}^{*}$ & 6.95 & 0.27 & 8.02 & 0.57 & 7.75 \\
\hline $\mathrm{MnO}$ & 0.13 & 0.02 & 0.15 & 0.04 & 0.11 \\
\hline $\mathrm{MgO}$ & 9.81 & 0.21 & 9.81 & 0.44 & 9.77 \\
\hline $\mathrm{CaO}$ & 13.46 & 0.14 & 13.28 & 0.71 & 12.11 \\
\hline $\mathrm{Na}_{2} \mathrm{O}$ & 1.70 & 0.08 & 1.78 & 0.24 & 2.01 \\
\hline $\mathrm{K}_{2} \mathrm{O}$ & 0.03 & 0.01 & 0.03 & 0.01 & 0.04 \\
\hline $\mathrm{Cr}_{2} \mathrm{O}_{3}$ & 0.06 & 0.03 & 0.10 & 0.00 & 0.03 \\
\hline
\end{tabular}

the mechanism proposed by Nakamura and Shimakita (1998). In this case, the melt composition surrounding plagioclase after a dissolution phase can be enriched in plagioclase components and depleted in other components, including $\mathrm{Ti}$ and $\mathrm{Fe}$. The ability of the melt surrounding a plagioclase phenocryst to recover its original composition will depend on the diffusion coefficients of relevant elements in silicate magmas, and as $\mathrm{Ti}$ is expected to diffuse slowly, its concentration in melt inclusions in plagioclase may be low.

In summary, homogenisation experiments with melt inclusions in MORB plagioclase phenocrysts can provide reliable estimates of crystallisation (trapping) temperature and the $\mathrm{MgO}, \mathrm{Al}_{2} \mathrm{O}_{3}, \mathrm{CaO}, \mathrm{Na}_{2} \mathrm{O}$, and $\mathrm{K}_{2} \mathrm{O}$ contents of the host magma at the moment of trapping. However, the concentrations of $\mathrm{TiO}_{2}, \mathrm{FeO}^{*}$, and $\mathrm{SiO}_{2}$ in homogenised inclusions do not reflect the composition of the host magma. An important con- clusion from these results is that $\mathrm{Mg} \#$ of melt inclusions in MORB plagioclase, widely believed to be unaffected by post-entrapment modification and often used to assess the degree of fractionation of the trapped melts (e.g., Nielsen et al., 1995; Sours-Page et al., 1999), are in fact, not representative of the melt composition at the time of trapping.

A detailed analysis of the processes affecting the compositions of melt inclusions in spinel is beyond the scope of this paper. However, our preliminary results on spinel from MORB, indicate that in general, concentrations of $\mathrm{TiO}_{2}, \mathrm{Na}_{2} \mathrm{O}, \mathrm{K}_{2} \mathrm{O}$ in homogenised or naturally quenched glassy inclusions reflect the composition of the host magma (McNeill, 1997). At the same time, $\mathrm{FeO}^{*}, \mathrm{Al}_{2} \mathrm{O}_{3}, \mathrm{CaO}, \mathrm{SiO}_{2}$, and $\mathrm{MgO}$ contents do not always reflect the composition of the host magma, and the behaviour of these elements varies between samples.

Due to the opaque nature of the host mineral, studies of melt inclusions in spinel are prone to additional complications. During reheating experiments, melting of any accidentally trapped phases can modify the initially trapped melt composition. The compositions of naturally quenched glassy melt inclusions can be affected by crystallisation on the accidentally trapped phases or by crystallisation of daughter phases, both may not be easily identified if they are not present on the opened plane of a sample. Both effects have been identified in melt inclusions in spinel from MORB (McNeill, 1997).

\section{Conclusions}

Melt inclusions in phenocrysts are potentially a powerful tool in petrological research that can provide the only direct information available on the physical parameters ( $P, T$ and melt composition) of crystallisation at various stages in the evolution of magmatic systems. However, melt inclusions also differ in principle from other parts of the magmatic system in that their composition, after trapping, may be controlled by the composition of the host phenocryst and therefore the direct application of our understanding of macro-scale magmatic processes to the interpretation of melt inclusion data can lead to erroneous conclusions. Our results indicate that the compositions of melt inclusions in early formed phe- 
nocrysts (olivine, pyroxene, plagioclase and spinel), often of most interest in petrological studies, can be affected by processes such as volatile dissociation, oxidation and/or partial re-equilibration with their host, both during natural cooling and homogenisation experiments. In particular, melt inclusions in all minerals are prone to hydrogen diffusion into or out of the inclusions after trapping and prior to eruption, and during homogenisation experiments. If not taken into account, this can significantly affect the crystallisation temperatures derived from the homogenisation experiments. Melt inclusions in high-magnesian olivine phenocrysts commonly have lower Fe contents compared to the initially trapped composition. This often leads to the appearance of sulphide globules, and in some cases, high-magnesian clinopyroxene daughter crystals, and may cause an increase in the oxidation state of the inclusions. Homogenised melt inclusions in plagioclase phenocrysts in MORB usually have lower $\mathrm{Ti}$ and $\mathrm{Fe}$, and higher Si contents compared to the melt composition at the moment of trapping. However, homogenisation experiments can provide reliable estimates of trapping temperature and the $\mathrm{MgO}, \mathrm{Al}_{2} \mathrm{O}_{3}, \mathrm{CaO}, \mathrm{Na}_{2} \mathrm{O}$, and $\mathrm{K}_{2} \mathrm{O}$ contents of the host magma at the moment of trapping.

Some of these processes can be identified by observing the behaviour of melt inclusions during homogenisation experiments using low-inertia visually controlled heating stages, and their effects can be minimised by using appropriate experimental conditions as determined by kinetic experiments, ideally completed for each phenocryst type in every sample.

The recent literature on melt inclusions is heavily biased toward the interpretation of the melt inclusion compositional data, whereas understanding the process affecting inclusion compositions after trapping receives very little attention. There is a clear need for this situation to change.

\section{Acknowledgements}

LVD acknowledges the support of the Australian Research Council through a Fellowship and Research Grants, and AMcN was supported by an Australian Post Graduate Research Award and AVS acknowledges support of Russian Basic Research Foundation (99-05-65319) and Alexander von Humboldt Award.
We also acknowledge the technical assistance of Wieslaw Jablonski, Graham Rowbottom and Keith Harris and the support of the Museum of Natural History, Washington DC, who provided electron microprobe standards. The original manuscript was improved by comments of two anonymous reviewers.

\section{References}

Anderson, A.T., 1974. Evidence for a picritic, volatile-rich magma beneath Mt. Shasta, California. J. Petrol. 15, 243-267.

Anderson, A.T., Brown, G.G., 1993. $\mathrm{CO}_{2}$ contents and formation pressures of some Kilauean melt inclusions. Am. Mineral. 78, 794-803.

Ariskin, A.A., Barmina, G.S., 1999. An empirical model for calculation of spinel-melt equilibria in mafic igneous systems at atmospheric pressure: 2. Fe-Ti oxides. Contrib. Mineral. Petrol. 134, 251-263.

Ariskin, A.A., Frenkel, M.Ya., Barmina, G.S., Nielsen, R., 1993. COMAGMAT: a Fortran program to model magma differentiation processes. Comput. Geosci. 19, 1155-1170.

Blundy, J.D., Wood, B.J., Davies, A., 1996. Thermodynamics of rare earth element partitioning between clinopyroxene and melt in the system $\mathrm{CaO}-\mathrm{MgO}-\mathrm{Al}_{2} \mathrm{O}_{3}-\mathrm{SiO}_{2}$. Geochim. Cosmochim. Acta 60, 359-364.

Christensen, J.N., DePaolo, D.J., 1993. Time scales of large volume silicic magma systems: $\mathrm{Sr}$ isotopic systematics of phenocrysts and glass from the Bishop Tuff, Long Valley, California. Contrib. Mineral. Petrol. 113, 100-114.

Clocchiatti, R., 1975. Glassy inclusions in crystals of quartz; optical, thermo-optical and chemical studies, and geological applications. Soc. Geol. Fr., Mem., New Series 54 (122), 96 pp.

Danyushevsky, L.V., 2001. The effect of small amounts of $\mathrm{H}_{2} \mathrm{O}$ on crystallisation of mid-ocean ridge and back-arc basin magmas. J. Volcanol. Geotherm. Res. (in press).

Danyushevsky, L.V., Sobolev, A.V., Falloon, T.J., 1995. North Tongan high-Ca boninite petrogenesis: the role of Samoan plume and subduction zone-transform fault transition. J. Geodyn. 20, $219-241$.

Danyushevsky, L.V., Carroll, M.R., Falloon, T.J., 1997. Origin of high-An plagioclase in Tongan high-Ca boninites: implications for plagioclase-melt equilibria at low $\mathrm{P}\left(\mathrm{H}_{2} \mathrm{O}\right)$. Can. Mineral. $35,313-326$.

Danyushevsky, L.V., Della-Pasqua, F.N., Sokolov, S., 2000a. Reequilibration of melt inclusions trapped by magnesian olivine phenocrysts from subduction-related magmas: petrological implications. Contrib. Mineral. Petrol. 138, 68-83.

Danyushevsky, L.V., Eggins, S.M., Falloon, T.J., Christie, D.M., 2000b. $\mathrm{H}_{2} \mathrm{O}$ abundance in depleted to moderately enriched mid-ocean ridge magmas: Part I. Incompatible behaviour, implications for mantle storage, and origin of regional variations. J. Petrol. 41, 1329-1364.

Dixon, J.E., Stolper, E.M., Holloway, J.R., 1995. An experimental study of water and carbon dioxide solubilities in mid-ocean 
ridge basaltic liquids: Part I. Calibration and solubility models. J. Petrol. 36, 1607-1631.

Eggins, S., 1993. Origin and differentiation of picritic arc magmas, Ambae (Aoba), Vanuatu. Contrib. Mineral. Petrol. 114, 79100.

Falloon, T.J., Danyushevsky, L.V., 2000. Melting of refractory mantle at 1.5, 2.0 and $2.5 \mathrm{GPa}$ under $\mathrm{H}_{2} \mathrm{O}$-undersaturated conditions: implications for the petrogenesis of high-Ca boninites and the influence of subduction components on mantle melting. J. Petrol. 41, 257-283.

Ford, C.E., Russel, D.G., Craven, J.A., Fisk, M.R., 1983. Olivineliquid equilibria: temperature, pressure and composition dependence of the crystal/liquid cation partition coefficients for $\mathrm{Mg}$, $\mathrm{Fe}^{2+}$, Ca and Mn. J. Petrol. 24, 256-265.

Gaetani, G.A., Watson, E.B., 2000. Open system behavior of olivine-hosted melt inclusions. Earth Planet. Sci. Lett. 183, $27-41$.

Grove, T.L., Kinzler, R.J., Bryan, W.B., 1992. Fractionation of midocean ridge basalt (MORB). Mantle flow and melt generation at mid-ocean ridges. AGU Geophysical Monograph, vol. 71. American Geophysical Union, Washington D.C., pp. 281-310.

Gurenko, A.A., Schmincke, H.-U., 2000. S concentrations and its speciation in Miocene basaltic magmas north and south of Gran Canaria (Canary Islands): constraints from glass inclusions in olivine and clinopyroxene. Geochim. Cosmochim. Acta 64, 2321-2337.

Gurenko, A.A., Polyakov, A.I., Kononkova, N.N., 1987. Immiscible sulphide segregations in minerals of early crystallisation stages of basaltic rock series. Trans. USSR Acad. Sci. 293 (2), $171-$ 174.

Gurenko, A.A., Hansteen, T.H., Schmincke, H.-U., 1996. Evolution of parental magmas of Miocene shield basalts of Gran Canaria (Canary Islands): constraints from crystal, melt and fluid inclusions in minerals. Contrib. Mineral. Petrol. 124, 422-435.

Hauri, E.H., 2002. SIMS analysis of volatiles in volcanic glasses: 2 . Isotopes and abundances in Hawaiian melt inclusions. Chem. Geol. 183, 117-143.

Johnson, K.T.M., Fisk, M.R., Naslund, H.R., 1995. Geochemical characteristics of refractory silicate melt inclusions from Leg 140 diabases. In: Erzinger, J., Becker, K., Dick, H.J.B., Stokking, L.B. (Eds.), Proc. Ocean Drill. Program: Sci. Results, vol. 137/140, pp. $131-139$.

Kamenetsky, V.S., Crawford, A.J., Eggins, S., Muhe, R., 1997. Phenocryst and melt inclusion chemistry of near-axis seamounts, Valu Fa Ridge, Lau Basin: insight into mantle wedge melting and addition of subduction components. Earth Planet. Sci. Lett. 151, 205-223.

Kamenetsky, V.S., Eggins, S.M., Crawford, A.J., Green, D.H., Gasparon, M., Falloon, T.J., 1998. Calcic melt inclusions in primitive olivine at $43^{\circ} \mathrm{N}$ MAR: evidence for melt-rock reaction/ melting involving clinopyroxene-rich lithologies during MORB generation. Earth Planet. Sci. Lett. 160, 115-132.

Lange, R.A., Carmichael, I.S.E., 1987. Densities of $\mathrm{Na}_{2} \mathrm{O}-\mathrm{K}_{2} \mathrm{O}-$ $\mathrm{CaO}-\mathrm{MgO}-\mathrm{FeO}-\mathrm{Fe}_{2} \mathrm{O}_{3}-\mathrm{Al}_{2} \mathrm{O}_{3}-\mathrm{TiO}_{2}-\mathrm{SiO}_{2}$ liquids: new measurements and derived partial molar properties. Geochim. Cosmochim. Acta 51, 2931-2946.

Libourel, G., 1999. Systematics of calcium partitioning between olivine and silicate melt: implications for melt structure and calcium content of magmatic olivines. Contrib. Mineral. Petrol. $136,63-80$.

Lu, F., Anderson, A.T., Davis, A.M., 1995. Diffusional gradients at the crystal/melt interface and their effect on the composition of melt inclusions. J. Geol. 103, 591-597.

McNeill, A.W., 1997. The crystallisation history of normal midocean ridge basalts from the eastern Pacific Ocean and implications for the composition of primary mid-ocean ridge magmas: evidence from mineralogy, pillow-rim glasses and melt inclusion studies. PhD Thesis, University of Tasmania, Hobart, 258 pp.

McNeill, A.W., Danyushevsky, L.V., 1996. Compositions and crystallization temperatures of primary melts for Hole 896A basalts: evidence from melt inclusion studies. Proc. Ocean Drill. Program: Sci. Results 148, 21-35.

Metrich, N., Clocchiatti, R., 1989. Melt inclusion investigation of the volatile behavior in historic alkaline magmas of Etna. Bull. Volcanol. 51, 185-198.

Metrich, N., Clocchiatti, R., 1996. Sulfur abundance and its speciation in oxidized alkaline melts. Geochim. Cosmochim. Acta 60, 4151-4160.

Metrich, N., Schiano, P., Clocchiatti, R., Maury, R.C., 1999. Transfer of sulfur in subduction settings: an example from Batan Island (Luzon volcanic arc, Philippines). Earth Planet. Sci. Lett. $167,1-14$.

Michael, P.J., McDonough, W.F., Nielsen, R.L., Cornell, W.C., 2002. Depleted melt inclusions in MORB plagioclase: messages from the mantle or mirages from the magma chamber? Chem. Geol. 183, 43-61.

Nakamura, N., Shimakita, S., 1998. Dissolution origin and syn-entrapment compositional change of melt inclusion in plagioclase. Earth Planet. Sci. Lett. 161, 119-133.

Nielsen, R.L., Crum, J., Bourgeois, R., Hascall, K., Forsythe, L.M., Fisk, M.R., Christie, D.M., 1995. Melt inclusions in high-An plagioclase from the Gorda Ridge: an example of the local diversity of MORB parent magmas. Contrib. Mineral. Petrol. 122, 34-50.

Nisbet, E.G., 1982. The tectonic setting and petrogenesis of komatiites. In: Arndt, N.T., Nisbet, E.G. (Eds.), Komatiites. George Allen \& Unwin, London, pp. 501-520.

Niu, Y., Batiza, R., 1991. In situ densities of MORB melts and residual mantle: implications for buoyancy forces beneath mid-ocean ridges. J. Geol. 99, 767-775.

Qin, Z., Lu, F., Anderson, A.T., 1992. Diffusive re-equilibration of melt and fluid inclusions. Am. Mineral. 77, 565-576.

Roedder, E., 1979. Origin and significance of magmatic inclusions. Bull. Mineral. 102, 487-510.

Roedder, E., 1984. Fluid inclusions. Rev. Mineral. 14, 620 pp.

Sinton, C.W., Christie, D.M., Coombs, V.L., Nielsen, R.L., Fisk, M.R., 1993. Near primary melt inclusions in anorthite phenocrysts from the Galapagos Platform. Earth Planet. Sci. Lett. 119, $527-537$.

Sisson, T.W., Bronto, S., 1998. Evidence for pressure-release melting beneath magmatic arcs from basalt at Galungnung, Indonesia. Nature 391, 883-886.

Sisson, T.W., Layne, G.D., 1993. $\mathrm{H}_{2} \mathrm{O}$ in basalt and basaltic andesite glass inclusions from 4 subduction-related volcanoes. Earth Planet. Sci. Lett. 117, 619-635. 
Sobolev, A.V., 1983. Origin of Siberian Meimechites in relation to the general problem of ultramafic magma. PhD Thesis, Vernadsky Institute of Geochemistry, Moscow, USSR, 300 pp. (in Russian).

Sobolev, A.V., 1996. Melt inclusions in minerals as a source of principle petrological information. Petrology 4, 228-239.

Sobolev, A.V., 2001. Implications of melt inclusions study in geodynamics: some tough questions about exotic inclusions. Abstracts EUG XI

Sobolev, A.V., Chaussidon, M., 1996. $\mathrm{H}_{2} \mathrm{O}$ concentrations in primary melts from island arcs and mid-ocean ridges: implications for $\mathrm{H}_{2} \mathrm{O}$ storage and recycling in the mantle. Earth Planet. Sci. Lett. 137, 45-55.

Sobolev, A.V., Danyushevsky, L.V., 1994. Petrology and geochemistry of boninites from the north termination of the Tonga Trench: constraints on the generation conditions of primary high-Ca boninite magmas. J. Petrol. 35, 1183-1211.

Sobolev, V.S., Kostyuk, V.P. (Eds.), 1975. Magmatic Crystallization Based on a Study of Melt Inclusions. Nauka, Novosibirsk, $184 \mathrm{pp}$.

Sobolev, A.V., Shimizu, N., 1993. Ultra-depleted primary melt included in an olivine from the Mid-Atlantic Ridge. Nature 363, $151-154$.

Sobolev, A.V., Dmitriev, L.V., Barsukov, V.L., Nevsorov, V.N., Slutsky, A.B., 1980. The formation conditions of the high-magnesian olivines from the monomineralic fraction of Luna 24 regolith. Proc. 11th Lunar Sci. Conf., 105-116.

Sobolev, A.V., Clocchiatti, R., Dhamelincourt, P., 1983. Les variations la temperature et de la pression partielle d'eau pendant la cristallisation de l'olivine dans les oceanites du Piton de la Four- naise (Reunion eruption de 1966). C. R. Acad. Sci., Paris 296, $275-280$.

Sobolev, A.V., Danyushevsky, L.V., Dmitriev, L.V., Suschevskaya, N.M., 1988. High-alumina magnesian tholeiite as one of primary basalt melts of basalts of the mid-oceanic ridges. Geokhimiya 10, 1522-1528 Translated into English in Geochem. Int., 1989, 26, 128-133.

Sobolev, A.V., Kamenetsky, V.S., Metrich, N., Clocchiatti, R., Kononkova, N.N., Devirts, A.L., Ustinov, V.I., 1990. Regime of volatile components and conditions of crystallization of hawaiite lavas of Etna Volcano, Sicily. Geokhimiya 9, 1277-1290. Translated into English in Geochem. Int. 1991, 28, 53-65.

Sobolev, A.V., Hofmann, A.W., Nikogosian, I.K., 2000. Recycled oceanic crust observed in 'ghost plagioclase' within the source of Mauna Loa lavas. Nature 404, 986-990.

Sours-Page, R., Johnson, K.T.M., Nielsen, R.L., Karsten, J.L., 1999. Local and regional variation of MORB parent magmas: evidence from melt inclusions from the Endeavour Segment of the Juan de Fuca Ridge. Conrtrib. Mineral. Petrol. 134, 342-363.

Sugawara, T., 2000. Thermodynamic analysis of Fe and Mg partitioning between plagioclase and silicate liquid. Contrib. Mineral. Petrol. 138, 101-113.

Tait, S., 1992. Selective preservation of melt inclusions in igneous phenocrysts. Am. Mineral. 77, 146-155.

Verbeeten, A., 1996. Petrology, geochemistry and tectonic implications of magmatism along the northern Hunter Ridge and Kadavu Island group, Fiji. PhD Thesis, University of Tasmania, Hobart, 190 pp.

Wallace, P., Carmichael, I.S.E., 1992. Sulfur in basaltic magmas. Geochim. Cosmochim. Acta 56, 1863-1874. 